\title{
Notes
}

\section{OCCUPATION OF THE WOMB: FORCED IMPREGNATION AS GENOCIDE}

\author{
SIOBHÁN K. FTSHER
}

INTRODUCTION

Rape during war, although prevalent throughout history, has only recently impressed the conscience of the world. ${ }^{1}$ Even then, rape has been treated as incidental to war, ${ }^{2}$ a product rather than a pohicy of military conflict. ${ }^{3}$ The mass rape of women during the war in the former Yugoslavia, ${ }^{4}$ however, has raised the question of how the act of rape gives rise to hability under international humanitarian law. ${ }^{5}$

1. See, e.g., Christine M. Chinkin, Peace and Force in International Law, in RECONCEIVING REALITY: WOMEN AND INTERNATIONAL LAW 203 (Dorinda G. Dallmeyer ed., 1993); Caroline D. Krass, Bringing the Perpetrators of Rape in the Balkans to Justice: Time for an International Criminal Court, 22 DENV. J. INT'L L. \& POLICY 317, 318 (1994); see generally SUSAN BROWNMILLER, AGAINST OUR WILL: MEN, WOMEN AND RAPE 23-133 (1975).

2. See Madeline Morris, By Force of Arms: Rape, War, and Military Culture, 45 DUKE L.J. 651, 652, 654 n.5 (1996).

3. Many argue that the distinction drawn in international law between public acts of the state and private acts of individuals has been an important factor in the failure of international law to address adequately the crime of rape. Rape has not been viewed as torture, or as imputable to the State, because it is committed by private actors, typically within private locations; it is instead seen as "unconscious and unorganized and unsystematic and unplanned." Catharine A. MacKinnon, On Torture: A Feminist Perspective on Human Rights, in HUMAN RIGHTS IN THE TWENTY-FIRST CENTURY: A GLOBAL ChaLLENGE 26 (Kathleen E. Mahoney \& Paul Mahoney eds., 1993); see also KaTARINA TOMASEVSKI, WOMEN AND HUMAN RIGHTS 89 (1993) (explaining that those who oppose the international movenent to condemn violence against women behieve that "only relations between the state and the individual pertain to human rights").

4. The Sarajevo State Commission for Investigation of War Crimes and the Croatian women's group Tresnjevka estimate that more than 50,000 women and children had been raped in the former Yugoslavia as of October, 1992. See Slavenka Drakulic, Women Hide Behind a Wall of Silence, in WHY BosNIA? 119 (Rabia Ale \& Lawrence Lifschultz eds., 1993). The European Community's Investigation Team estimates that about 20,000 women were raped as of early 1993. See European Community Investigative Mission into the Treatment of Muslim Women in the Former Yugoslavia, U.N. SCOR, 48th Sess., Aumex I, U.N. Doc. S/25240, at 5 (1993). Though reported statistics differ, rape has undeniably occurred on a large scale in the war in the former Yugoslavia. See Chinkin, supra note 1 , at 1 .

5. See Shana Swiss \& Joan E. Giller, Rape as a Crime of War: A Medical Perspec- 
The conflict in the former Yugoslavia also raises a question beyond the criminal treatment of rape during war. For perhaps the first time in modern history, an aggressor in a military conflict inay have used rape not only as a tool of war, but also to implement a policy of impregnation in order to further the destruction of one people and the proliferation of another-a policy of genocide by forced impregnation. ${ }^{6}$ Notwithstanding the prevalence of

tive, 270 JAMA 612, 612 (1993). The international media's focus on rape, torture and forced pregnancy is one of the primary motivating factors behind the international legal community's attempts to enforce humanitarian law. But see Bert V.A. Röling, Aspects of the Criminal Responsibility for Violations of the Laws of War, in THE NEW HUMANITARIAN LAW OF ARMED CONFLICT 199-200 (Antonio Cassese ed., 1979) (viewing the influence of public opinion as weak).

6. This Note presents legal analysis of the act of forced impregnation and asserts that forced impregnation is a crine distinct from rape. It is not a fact-flnding report, nor does it purport to document the prevalence of forced inpregnation in the war in the former Yugoslavia.

"Forced impregnation" can be defined as an impregnation that results from an assault or series of assaults on a woman perpetrated with the intent that she become pregnant. ... The requisite criminal intent can be established either directly, through admissions or statements of the perpetrators, or indirectly, through circumstantial evidence. Forcible removal of a woman's IUD or contraceptive implant, or destruction of other means of birth control or access to birth control, would constitute evidence of intent to impregnate. The intentional detention of a pregnant woman until she was beyond the time limit in which local law or practice permits abortion would also constitute evidence of violation. Mandatory pregnancy tests following a rape, or attempts to keep track of a detained woinan's menstrual cycle (especially if she were assaulted more frequently around the time she ovulated) similarly would be evidence of the requisite intent.

ANNE TIERNEY GOLDSTEN, RECOGNIZING FORCED IMPREGNATION AS A WAR CRIME UNDER INTERNATIONAI LAW 4 (1993). These examples of the requisite intent are not intended to exhaust the means by which criminal intent may be demonstrated. See id. at 4 n.8.

Rape may be used to achieve forced impregnation, but forced impregnation can be perpetrated by means other than rape, such as forced artificial insemination. Technology has been used as a means of reproductive control in the past. For example, Nazi doctors experimented with what were at the time highly advanced surgical and nonsurgical means of sterilizing concentration camp victims. See id. at $4 \mathrm{n} .7$ (citing Telford Taylor, Opening Statement of the Prosecution, December 9, 1946, reprinted in THE NAZI DOCTORS AND THE NUREMBERg CODE: HuMAN RIGHTS IN HUMAN EXPERIMENTATION 67-81 (George J. Annas \& Michael A. Grodin eds., 1992)). Helsinki Watch, a division of Human Rights Watch, takes the position that forced impregnation is distinct from rape, and should be punished as such. "In our view, the forcible impregnation of women, or the intention to so impregnate them, constitutes an abuse separate from the rape itself and should be denounced and investigated as such." 2 HELSINKI WATCH, WAR CRIMES IN BOSNIAHERCEGOVINA 21 (1993) [hereinafter 2 WAR CRIMES IN BOSNIA-HERCEgovina].

In this Note, the term "rape" refers to the general category of sexual assault perpetrated in the form of bodily penetration by means of an animate or inaninate mechanism. On the other hand, the phrase "forced impregnation" is used only in the limited 
rape in the former Yugoslavia and its obvious connection with the resulting pregnancies, forced impregnation is a crime distinct from the crime of rape. ${ }^{7}$ Rape might be used to achieve forced impregnation, but forced impregnation can be perpetrated by means other than rape.

This Note argues that forced impregnation, as an intentional policy of an aggressor to destroy a group of people, is distinct from the crime of rape and is, at its core, a crime of genocide. ${ }^{8}$ Genocide, as defined in the Genocide Convention of 1948, involves the destruction of a group of people. ${ }^{9}$ It may seem countermtuitive that impregnation, the creation of new life, can in fact be an instrument of genocide. But forced impregnation-interference with autonomous reproduction-can destroy a group. This interference in the group's reproduction may take a number of forms. First, women may be psychologically traumatized by the pregnancy and unable to have normal sexual or childbearing experiences with members of their own group. Second, women who are raped and bear the children of the aggressors may no longer be marriageable in their society. Third, the woinen, simply because they are pregnant with the children of the aggressors, cannot bear their own children during this time-their wombs are "occupied."

Interference with the reproductive capacity of a group has severe inphications for the psychological, religious and ethnic identity of the group. Tautologically, nothing is more vital to the continued existence of a group of people than its ability to reproduce. A deliberate policy of forced impregnation thus may constitute a

sense of the act of forcibly causing conception to occur.

7. See 2 WAR CRIMES IN BOSNIA-Hercegovina, supra note 6 , at 21 .

8. The conflict in the former Yugoslavia has given rise to vehement allegations that genocide was attempted against the Bosnian Muslims. See generally ROY GUTMAN, A WITNESS TO GENOCIDE (1993). These allegations go hand in hand with claims that mass rape and forced impregnation were part of such a plan of genocide. See id. at 164 (describing these atrocities as "organized and systematic"). This Note atteinpts to sift through those general allegations of genocide to focus only on the issue of forced inpregnation.

9. See Convention on the Prevention and Punishment of the Crime of Genocide, adopted Dec. 9, 1948, G.A. Res. 260A(III), 78 U.N.T.S. 277 (entered into force Jan 12, 1951) [hereinafter Genocide Convention]. The United States was an original signatory nation to the convention, but the U.S. Senate did not ratify the Convention until 1986. See S. REP. No. 100-333 at 2 (1988), reprinted in U.S.C.C.A.N. 4156, 4157. The Convention became effective in the United States two years later with the adoption of the Genocide Convention Implenientation Act, Pub. L. 100-606, 102 Stat. 3045 (1988). See S. REP. NO. 100-333. 
genocidal attempt to destroy a group of people. This Note argues that when forced impregnation is part of a policy to destroy a group, it should be prosecuted under the Genocide Convention. ${ }^{10}$

Despite widespread allegations of forced impregnation in the former Yugoslavia by the news media and investigatory reports of the United Nations, the European Community, and liuman riglts groups ${ }^{11}$ inany still deny the existence of such a policy, arguing that rape was a sporadic and minimal occurrence. ${ }^{12}$ The purpose of this Note is not to confirm the truth of these allegations of forced impregnation.

Instead, the Note examines allegations of genocidal forced impregnation in their historical and cultural context and argues two propositions: first, there is extensive evidence which supports allegations of forced impregnation; and second, if such allegations are substantiated in a court of law, the act of forced impregnation should be prosecuted as a crime of genocide rather than under the umbrella of other war crimes. Part I asserts that forced impregnation is a crime that falls under international liuniamitarian law as a war crime and a crime against liunianity, discussing liow war crimes and crimes against humanity differ from the crime of genocide. Part II addresses the evidence of widespread rape in the former Yugoslavia and low the nature of those acts indicates a policy of forced impregnation. Part III places this evidence of a forced impregnation pohicy within the ethunc context of the former Yugoslavia. Finally, Part IV argues that the Serb policy of forced impregnation, if it existed, was genocide, and that the International Tribunal for the former Yugoslavia should prosecute such a policy as a crime of genocide.

10. See Genocide Convention, supra note 9; infra notes 219-48 and accompanying text.

11. See infra notes $87-123$ and accompanying text.

12. Official Serb sources denied the occurrence of forced impregnation, but captured Serb soldiers admitted that it had taken place. For examples of such denials, see Lance Morrow, Unspeakable, TIME, Feb. 22, 1993, at 48; Sherry Ricchiardi, Bosnian Rape Victims Tell of Terror, Sr. LouIS POST-DISPATCH, Feb. 8, 1993, at 1B; Bosnian Serb Leader Karadzic Denies Mass Rapes, Reuters Financial Service, Feb. 5, 1993, available in LEXIS, World Library, Txtlne File; For the Record, WASH. POST, Feb. 5, 1993, at A24. A few scholars also dispute that rape and forced impregnation were part of a plan or policy. See, e.g., PAUL MoJZES, YugosLAVIAN INFERNo 168-69 (1994) (noting that "[w]ithout question, women were raped both spontaneously and with calculation, but it is doubtful that governments sent instructions in that regard"). 


\section{INTERNATIONAL HUMANITARIAN LAW AND FORCED IMPREGNATION}

Forced impregnation, as such, is not explicitly defined as a crime under international humanitarian law. ${ }^{13}$ Similarly, rape is often not exphicitly enumerated as a crime under international humanitarian law, but it has been generally accepted that rape falls under the definitions of crimes against international humanitarian law, including "war crimes," "grave breaches" of the Geneva Conventions, and "crimes against humarity." Although this Note focuses specifically on the crime of forced impregnation, parallels nuay be drawn between how rape is treated under international humanitarian law and how forced impregnation may be addressed under these same laws.

At present, several international legal regimes exist to address the crime of rape during wartime. ${ }^{15}$ Rape and other forms of sex-

13. See GOLDSTEN, supra note 6, at 3. "If rape is nearly invisible [in international humanitarian law], forcible impregnation is its faintest slradow. It lias never been explicitly recognized or redressed as a war crime by any international convention or tribimal, nor has it been examined in the scholarship of humanitarian law." Id.

14. Id. at 4. "[F]orced impregnation is a war crime under current international humanitarian law." Id. Rape may also be encompassed by other international laws such as the International Covenant on Civil and Political Rights, G.A. Res. 2200, U.N. GAOR, 21st Sess., Supp. No. 16, at 52, U.N. Doc. A/6316 (1967), or The Convention Against Torture and Other Cruel Inhuman or Degrading Treatment or Punishment, G.A. Res. 39/46, U.N. GAOR, 39tl Sess., Supp. No. 51, at 197, U.N. Doc. A/39/51 (1984).

15. International law prohibiting rape developed over many centuries. "There is no precise moment in history when bells clanged and rape in war universally came to be considered a criminal act, outside the province of a proper warrior. The historic development of the riglits of women, like the development of nations, proceeded at an uneven pace." BROWNMILLER, supra note 1 , at 27 . Totila, the Ostrogoth who captured Rome in 546 A.D., was one of the first to prohibit rape in wartinie. See id. By the Middle Ages, a woman's right to bodily integrity began to be recognized. See id. Customary law prohibiting rape emerged, and in some cases was codified in military regulations. See Leslie C. Green, What One May Do In Combat-Then and Now, im HUMANITARIAN LAW OF ARMEd CONFlict: Challenges AHEAD 277 (Astrid J.M. Delissen \& Gerard J. Tanja eds., 1991). By the fifteenth century, violence against women was even considered a capital offense in some armies. See id. at 281. Yet,

as late as the seventeenth century, the Dutch jurist Grotius, who wrote at length on international nilitary law, was forced to nuse that some countries held that the dishonoring of women in war was allowable while other countries lield to the contrary.... The outlawing of rape in warfare, at least on the books, was an important advance for women, but despite the penalties, and whether or not they were rigorously applied, rape in warfare continued to flourish.

BROWNMILLER, supra note 1 , at 27 . By the nineteenth century imdividual states and the international community began to codify customary international law of humanitarian 
ual abuse are clear violations of such instruments of international humanitarian law as the Geneva Conventions of 1949, the 1977 Additional Protocols, and the body of law developed through the charters and judgments of the Nuremberg and Tokyo Tribunals. ${ }^{16}$ By analogy, forced impregnation also may fall under this body of international humanitarian law.

\section{A. The Geneva Conventions \\ The Geneva Conventions were drafted as a response to atroc- ities committed during World War $\Pi{ }^{17}$ "Grave breaches" of the}

conduct. See Green, supra, at 277-78. Rape was considered a grave offense against the rules of war, although it was not always explicitly codified as such. See id. at 281 . The law of rape has continued to develop throughout the twentieth century. See id. at 281-82.

16. See infra notes 17-69 and accompanying text. The international laws of war before World War II did not designate rape as a war crime, although it was certainly proscribed by customary international law. The Hague Conventions of 1899 and 1907 do not specifically mention rape. See Convention with Respect to the Laws and Customs of War on Land, July 29, 1899, reprinted in 1 CHARLES I. BEVANS, TREATIES AND OTHER INTERNATIONAL AGREEMENTS OF THE UNITED STATES OF AMERICA 1776-1949 247 (1968); Convention Respecting the Laws and Customs of War on Land, Oct. 18, 1907, reprinted in 1 BEVANS, supra, at 631. However, the Preamble of the Conventions reaffirmed customary law in force at the time, which clearly prohibited rape. See id. at 633; Theodor Meron, Rape as a Crime Under International Humanitarian Law, 87 AM. J. INT'L L. 424, 425 (1993) (detailing the history of customary prohibitions against rape). Also, an annex to the conventions contains a provision commanding respect for "Family honour and rights $\ldots$ as well as religious convictions and practices ..." 3 BEVANS, supra, at 260,651 . This provision has been interpreted to prohibit rape. See YougnNRA KHUSHALANI, DIGNITY AND HONOUR OF WOMEN AS BASIC AND FUNDAMENTAL HUMAN RIGHTS 10 (1982) (asserting that Article 46 of the Hague Regulations is a mandatory provision guaranteeing women protection against rape).

17. See, e.g., Meron, supra note 16, at 424 (stating that Nazi atrocities led to the shaping of the Fourth Geneva Convention). The Geneva Conventions and Additional Protocols I and II are the primary instruments proscribing certain acts during war. The Geneva Conventions were drafted after World War II. See Convention Relative to the Treatinent of Prisoners of War, opened for signature Aug. 12, 1949, 6 U.S.T. 3316, 75 U.N.T.S. 135 [hereinafter Third Geneva Convention]; Convention Relative to the Protection of Civilian Persons im Time of War, opened for signature Aug. 12, 1949, 6 U.S.T. 3516, 75 U.N.T.S. 287 [hereinafter Fourth Geneva Convention]. Several decades later the Additional Protocols were drafted to further address treatment of civilians in wartime. See Protocol I Additional to the Geneva Convention of Aug. 12, 1949, and Relating to the Protection of Victims of International Armed Confiicts, opened for signature Dec. 12, 1977, 1125 U.N.T.S. 3 (entered into force Dec. 7, 1978) [hereinafter Additional Protocol I]; Protocol II Additional to the Geneva Conventions of Aug. 12, 1949 and Relating to the Protection of Victims of Non-International Armed Conflicts, opened for signature Dec. 12, 1977, 1125 U.N.T.S. 609, 612 (entered into force Dec. 7, 1978) [hereinafter Additional Protocol II].

Signatory states to the Geneva Conventions undertake to prosecute violations of the laws and customs of war by troops under their authority and command, for violations 
Geneva Conventions are actionable as war crimes. ${ }^{18}$ The Geneva Conventions do not specifically list rape among the grave breaches subject to universal jurisdiction, for which all signatories would be obliged to seek out and prosecute offenders. ${ }^{19}$ However, interpretations of the Conventions by the International Committee of the Red Cross, the United Nations, and the United States State Department all consider rape a grave breacli. ${ }^{20}$

The Geneva Convention Relative to the Treatment of Prisoners of War (The Third Geneva Convention) ${ }^{21}$ contains two provisions interpreted to proscribe rape. ${ }^{22}$ Article 13 states that "pris-

of internationally guaranteed human rights, and for wrongdoing to aliens under the normal principles of state responsibility. See GEOFFREY BEST, WAR \& LAW SINCE 1945, 115 (1994). Individuals can be held criminally responsible for war crimes. See Röling, supra note 5 , at 199, 200-03. This means that individuals, and not states, can be prosecuted for violations of the conventions. See id.

18. See Theodor Meron, The Case for War Crimes Trials in Yugoslavia, 72 ForeIGN AFF., Summer 1993, at 127-29. Violations of Common Article 3 of the Geneva Conventions do not constitute grave breaches giving rise to universal criminal jurisdiction. See id. at 128 .

19. See Fourth Geneva Convention, supra note 17, 6 U.S.T. at 3618,75 U.N.T.S. at 388.

20. See Meron, supra note 16 , at $426-27$.

The State department stated that:

[T] he legal basis for prosecuting troops for rape is well established under the Geneva Conventions and customary international law. As stated in the authoritative Department of the Army Law of War Manual, any violation of the Geneva Convention is a war crime. Article 27 of the Geneva Convention Relative to the Protection of Civilian Persons in Time of War provides that women shall be "especially protected ... against rape." Article 13 of the Geneva Convention Relative to the Treatment of Prisoners of War provides that prisoners "must at all times be protected, particularly against acts of violence"; article 14 requires that women "be treated with all the regard due to their sex." Both Conventions list grave breaches, including willful killing, torture or inhuman treatment, and (with regard to civilians) willfully causing great suffering or serious injury to body or health. Under the Geneva Conventions and customary international law, all parties to an international conflict (including all parties to the conflict in the former Yugoslavia) are required either to try persons alleged to have committed grave breaches or to extradite them to a party that will.

$$
\text { ... }
$$

In our reports to the United Nations on human rights violations in the former Yugoslavia, we have reported sexual assaults as grave breaches. We will continue to do so and will continue to press the imternational community to respond to the terrible sexual atrocities in the former Yugoslavia.

Letter from Robert A. Bradtke, Acting Assistant Secretary for Legislative Affairs, to Senator Arlen Specter (Jan. 27, 1993), reprinted in Meron, supra note 16, at 427 n.22. This interpretation is also reflected in the draft charters of the International Tribunal Statute submitted by states to the U.N. Secretary-General pursuant to Security Council Resolution 808. Id. at 427.

21. Third Geneva Convention, supra note 17.

22. See Letter from Robert A. Bradtke, supra note 20. 
oners of war must at all times be protected, particularly against acts of violence or intimidation and against insults and public curiosity."23 Article 14 states that "[w]omen shall be treated with all the regard due to their sex and sliall in all cases benefit by treatment as favourable as that granted to men." ${ }^{24}$ Both of these provisions are interpreted to proscribe rape, ${ }^{25}$ and, by analogy, forced impregnation. Forcibly impregnating a woman is not protecting lier against acts of violence, intimidation or insult; nor does it show any regard for her as a woman.

The Geneva Convention Relative to the Protection of Civilian Persons in Time of War (Fourth Geneva Convention) ${ }^{26}$ addresses the treatment of civilians in the hands of an adversary. ${ }^{27}$ Three provisions of this Convention either explicitly prohibit rape or have been interpreted to proscribe rape..$^{28}$ First, Article 3, which is apphicable to wars "not of an international character"29 such as internal insurgencies, prohibits violence to life and person as well as outrages upon personal dignity. ${ }^{30}$ Second, Article 27, apphicable to international conflicts, provides that " $[\mathrm{w}]$ omen shall be especially protected against any attack on their honour, in particular against rape, enforced prostitution, or any form of indecent assault." And third, Article 147 states that "torture or inhuman treatment" and "wilfully causing great suffering or serious injury to body or health" are "[g]rave breaches" of the Conventions. ${ }^{32}$

Forced pregnancy may cause injury to a woman's "body or health." Even if a court were not to constrne a healthy pregnancy, albeit forced, as an injury to body or health, the International

23. Third Geneva Convention, supra note 17, 6 U.S.T. at 3328, 75 U.N.T.S. at 146.

24. Id. 6 U.S.T. at 3330,75 U.N.T.S. at 148.

25. See Meron, supra note 16 , at $425-26$.

26. See Fourth Geneva Convention, supra note 17.

27. In the Fourth Geneva Convention, "protected persons" are defined by article 4 of the Convention as: "those who, at a given moment and in any manner whatsoever, find themselves, $\dot{m}$ case of a conflict or occupation, in the hands of a Party to the conflict or Occupying Power of which they are not nationals." Id., 6 U.S.T. at 3520, 75 U.N.T.S. at 290.

28. See Meron, supra note 16 , at $426-27$.

29. Fourth Geneva Convention, supra note 17, 6 U.S.T. at 3518, 75 U.N.T.S. at 288.

30. See id., 6 U.S.T. at 3518, 3520, 75 U.N.T.S. at 288, 290.

31. Id., 6 U.S.T. at 3536, 75 U.N.T.S. at 306. Additional Protocol I similarly prohibits "[o]utrages upon personal dignity, in particular humiliating and degrading treatment, enforccd prostitution and any form of indecent assault . . . " Additional Protocol I, supra note 17,1125 U.N.T.S. at 37.

32. Fourth Geneva Convention, supra note 17, 6 U.S.T. at 3618,75 U.N.T.S. at 388. 
Committee of the Red Cross Commentary to the Geneva Conventions (ICRC Commentary) explains that "'inhuman treatment' . . . does not include only physical injury or injury to health. Certain measures ... which caused grave injury to [a person's] human dignity, could conceivably be considered as inhuman treatment." ${ }^{.33}$ The forced carrying of a child of the enemy can certainly be interpreted as an injury to human dignity. ${ }^{34}$ The ICRC Commentary also interprets the phrase "wilfully causing great suffering" to encompass "punishment, in revenge or for some other notive, perhaps out of pure sadisn1. . . [that] can quite legitimately be held to cover inoral suffering also." 35 The ICRC interprets "inhuman treatment" to encoinpass "moral suffering." 36 Therefore, moral suffering resulting from forced pregnancy also falls under the terin "inhuman treatment."

Additional Protocol I to the Geneva Conventions also proscribes rape. Article 75(2) prohibits "violence to life, health, or physical or mental well-being of persons,"37 and Article 76(1) requires that wonien "shall be protected in particular against rape, forced prostitution and any other form of indecent assault."38 Article 4(2)(e) of Additional Protocol II, which applies in situations of non-international armed conflict, proscribes "outrages upon personal dignity, in particular liumiliating and degrading treatınent,

33. 1977 ICRC COMMENTARY 598-99, quoted in 2 WAR CRIMES IN BOSNIAHERCEGOVINA, supra note 6 , at 20 n.12.

34. See infra notes 184-205 and accompanying text.

35. 1977 ICRC COMMENTARY 598-99, quoted in 2 WAR CRIMES IN BOSNIAHERCEGOVINA, supra note 6 , at 20 n.12.

36. $I d$.

37. Article 75(2) of Additional Protocol I states:

The following acts are and shall remain prohibited at any time and in any place whatsoever, whether committed by civilian or by military agents:

(a) Violence to the life, health, or physical or inental well-being of persons, in particular:

(i) Murder;

(ii) Torture of all kinds, whether physical or mental;

(iii) Corporal punishment; and

(iv) [Mutilation];

(b) Outrages upon personal dignity, in particular humihating and degrad-

ing treatment, enforced prostitution and any form of indecent assault;

(c) The taking of hostages;

(d) Collective punishments; and

(e) Threats to commit any of the foregoing acts.

Additional Protocol I, supra note 17, at 1125 U.N.T.S. 37 (brackets in original).

38. Id. at 38. 
rape, enforced prostitution and any form of indecent assault" when committed against persons who do not take a direct part or who have ceased to take part in hostilities. ${ }^{39}$ Forced impregnation, as a "humiliating," degrading," and "indecent" assault, also falls within the Additional Protocols.

Whether the conflict in the former Yugoslavia is treated as internal or international is extremely important for the treatment of rape under international law. ${ }^{40}$ The "grave breaches" provision of the Geneva Conventions and Additional Protocol I is directed to international conflicts, and grave breaches must have been coinmitted in an armed conflict. ${ }^{41}$ But the question of when the war in the former Yugoslavia became an international conflict is a inatter of dispute.42 Thus, the requirement of a "war-nexus" might create probleins for adjudication of forced impregnation in the former Yugoslavia because, if at the time of the commission

39. Additional Protocol II, supra note 17, at 1125 U.N.T.S. 612.

40. See infra note 42 .

41. Violations of common article 3 of the Geneva Conventions, which applies to internal wars, do not constitute grave breaches giving rise to universal criminal jurisdiction. See Meron, supra note 18 , at 127.

42. The transition from internal to international conflict involves the recognition by the international community of the parties involved and whether the parties are solely internal groups or also sovereign nations. The exact nature of the involvement of the Federal Republic of Yugoslavia (Serbia and Montenego) in the conflict is crucial to this question. The various proposals for establishing an International Tribunal treat all aspects of the conflict as international and thus subject to prosecution for "classic" war crimes and grave breaches of the Geneva Conventions without explicitly addressing Serbia's involvement. Similarly, resolutions of the United Nations Security Council related to the violations in Bosnia assume that these violations are governed by provisions of the Geneva Conventions that are applicable in international armed conflict. See, e.g., S. Res. 771, U.N. SCOR, 47th Sess., at 25, U.N. Doc. S/INF/48 (1992); S. Res. 780, U.N. SCOR, 47th Sess., at 36, U.N. Doc. S/INF/48 (1992); S. Res. 808, U.N. SCOR, 48th Sess., 3175th mtg., U.N. Doc. S/RES/808 (1993); Letter from the Secretary-General Addressed to the Security Council (Feb. 9, 1993), U.N. SCOR, 48th Sess., at 1, U.N. Doc. S/25274 (1993); Interim Report of the Commission of Experts Established Pursuant to Security Council Resolution 780 (1992), U.N. SCOR, 48th Sess., Annex I, at 3, U.N. Doc. S/25274 (1993) [hereinafter Interim Report on Resolution 780]; see also Theodor Meron, War Crimes in Yugoslavia and the Development of International Law, 88 AM. J. INT'L L. 78 (1994).

The U.N. War Crimes Commission also considers the conflict to be international. The Commission stated, "[T]he character and complexity of the armed conflicts concerned, combined with the web of agreements on humanitarian issues the parties have concluded among themselves, justify an approach whereby it applies the law applicable in international armed conflicts to the entirety of the armed conflicts in the territory of the former Yugoslavia." Interim Report on Resolution 780, supra, at 14; see also Meron, supra note 18, at 128 (discussing the nature of the conflict and noting that there has been a broad consensus outside Yugoslavia that the conflict is international). 
of the crime the conflict is deemed internal, those accused of forced impregnation could challenge prosecutions for war crimes and grave breaches on grounds of lack of applicability of these Conventions. Acts which otlerwise meet the definition of grave breaches might fail the requirement that they be committed in an international armed conflict. ${ }^{43}$ Prosecution as a crime against humanity, however, does not pose this problem.

\section{B. Crimes Against Humanity}

The post-World War III concept of crimes against liumanity evolved to embrace crimes committed against civilians which might not be considered "war crimes." 44 The term "crime against liumanity" was first defined in the Nuremberg trials. ${ }^{45}$ Unlike grave breaches of the Geneva Conventions, crimes against humanity need not be committed during an armed conflict. ${ }^{46}$ For actions to come within the category of crimes against humamity they must be committed against a civilian population, not merely imdividual civilians, ${ }^{47}$ and it is necessary to prove systematic governmental planning of the acts committed. ${ }^{48}$ Rape, like murder, extermination, and deportation, is considered a constituent crime against humanity only when it is committed as part of a mass pattern of

43. Also, the charge of a grave breach might be challenged because rape has been specifically defined only as a crime against humanity. However, it may be interpreted to fall under the International Covenant on Civil and Political Rights, supra note 14, at 52, 53, or The Convention Against Torture and Other Cruel, Inhuman or Degrading Treatment or Punishment, supra note 14, at 197.

The Vienna Declaration of the World Conference on Human Rights also calls for the prosecution of crimes against women: "[v]iolations of the human rights of women in situations of armed conflict are violations of the fundamental principles of international human rights and humanitarian law. All violations of this kind, including in particular murder, systematic rape, sexual slavery, and forced pregnancy, require a particularly effective response." Vienna Declaration and Programme of Action, United Nations World Conference on Human Rights, U.N. GAOR, 47th Sess., at 37, U.N. Doc. A/C157/24 (Part I) (1993).

44. Agreement Concerning Prosecution and Punishment of the Major War Crininals of the European Axis, Aug. 8, 1945, Charter of the International Miktary Tribunal, art. 6(c), 59 Stat. 1546, 1547, 82 U.N.T.S. 284, 288 [hereinafter Nuremberg Charter].

45. See id.

46. See, e.g., Elements of the International Crime of "Crimes Against Humanity" Applied in the Former Yugoslavia, in 2 WAR CRIMES IN BOSNIA-HERCEGOVINA, supra note 5, at 394-97, app. a.

47. See Meron, supra note 16 , at 428 .

48. See 15 UNITED NATIONS WAR CRIMES COMM'N, LAW REPORTS OF TRIALS OF WAR CRMMNALS 134-36 (1949). 
crimes. ${ }^{49}$ These requirements make crimes against humanity more difficult to prove than war crimes or grave breaches. ${ }^{50}$

Despite the perpetration of mass rape during World War II, the Charter of the International Military Tribunal ("Nuremberg Charter")-the basis for the Nuremberg trials-did not initially include specific provisions for rape. ${ }^{51}$ The Nuremberg Charter prohibited the ill-treatment of civilians as a war crime and named "inhumane acts committed against any civilian population" as "[c]rimes against humanity." 52 Article 6(c) of the Nuremberg Charter defined crimes against humaunty as:

murder, extermination, enslavement, deportation, and other inhumane acts committed against any civilian population, before or during the war, or persecutions on political, racial or religious grounds in execution of or in connection with any crime within the jurisdiction of the Tribunal, whether or not in violation of the domestic law of the country where perpetrated. ${ }^{53}$

The Nuremberg Charter was later interpreted by the occupying powers to include rape both under the prohibition of "traditional war crimes" and "crimes against humamity." This imterpretation is still authoritative precedent. ${ }^{55}$

49. "[T]he massive and systematic practice of rape and its use as a 'national' instrument of 'ethnic cleansing' qualify it to be defined and prosecuted as a crime against humanity." Meron, supra note 16 , at $426-27$.

50. Id. at 428 ("The acquisition of facts supporting policy planning, mass claracter and command responsibility may present evidentiary hurdles to possible prosecutions.").

51. See Nuremberg Charter, supra note 44. Rape was not prosecuted at the Nuremberg trials. See generally 15 UNITED NATIONS WAR CRIMES COMM'N, supra note 48 , at $134-36$.

52. 82 U.N.T.S. at 288.

53. Id.

54. Control Council Law No. 10, adopted by the allies as a charter for war crimes by their national courts, expanded the list of crimes against humanity to include rape. Control Council Law No. 10, Dec. 20, 1945, reprinted in NAVAL WAR COLLEGE, DocuMENTS OF PRISONERS OF WAR 304 (Howard S. Levie ed., 1979). The law defined crimes aganist humanity as "[a]trocities and offences, including but not limited to murder, extermination, enslavement, deportation, imprisonment, torture, rape or other inhumane acts committed against any civilian population."' M. Cherif Bassiouni, International Law and the Holocaust, 9 CAL. W. INT'L L.J. 2D, 231 (1979); see also Meron, supra note 16, at 426.

55. See Diane F. Orentlicher, Settling Accounts: The Duty To Prosecute Human Rights Violations of a Prior Regime, 100 YALE L.J. 2537, 2587, 2587 n.224 (1991) (discussing the interpretation of the Nuremberg Charter in Control Council Law No. 10 to include rape). 
More recently, Human Rights Watch issued a Memorandum of Law that set forth the elements of crimes against humanity as apphed in the former Yugoslavia:

(i) Such crimes as murder, extermination, enslavement, deportation, and rape, and other similarly inhumane acts; or

(ii) persecutions on political, racial, or religious grounds, but which are carried out by means of crimes either the same as or of a nature not less serious than the crimes described in (i);

(iii) committed agamst any civilian population whether ill conformity with or in violation of domestic law governing such civilians; and

(iv) committed on a mass scale. ${ }^{56}$

This definition takes into account limiting interpretations of certain terms im the final Judgment of the Nuremberg Tribunal, and limitations of certain terms found in the decisions of other Allied war crimes tribunals interpreting similar language. ${ }^{57}$ Therefore, the Human Rights Watch definition is narrower than that provided in Article $6(\mathrm{c})$ of the Nuremberg Charter. Nevertheless, because the definition still includes rape, and it can, by analogy, be interpreted to include forced impregnation.

\section{War Crimes Trials}

At the Nuremberg Trials, rape was not charged in the indictments of Nazis. ${ }^{58}$ Rape arose only as a peripheral issue. For example, rape was considered as a method of military retaliation or reprisal during the French prosecution, and accounts of punitive measures taken by the Germans during 1944 were submitted as evidence. ${ }^{59}$ Sexual forms of torture, including rape, were docu-

56. See 2 WAR CRIMES IN BOSNIA-HERCEGOVINA, supra note 6, at 394-97.

57. See id. at 395 .

58. The International Military Tribunal at Nuremberg focused primarily on the mass extermination committed during the war rather than on rape. Only forced prostitution, not rape, was prosecuted. See 15 UNITED NATIONS WAR CRIMES COMM'N, supra note 48, at 121 ("Enforced Prostitution was punished as a war crime in the trial before a Netherlands Temporary Court Martial in Batavia of Washio Awochi.") Jennifer Green et al, Affecting the Rules for the Prosecution of Rape and Other Gender-Based Violence Before the International Criminal Tribunal for the Former Yugoslavia: A Feminist Proposal and Critique, 5 HASTINGS WOMEN's L.J. 171, 173 n.5 (1994).

59. BROWNMILLER, supra note $\mathbf{1}$, at $\mathbf{5 2}$. 
mented at Nuremberg but were not prosecuted as independent crimes. ${ }^{60}$

Unlike the Nuremberg Tribunal, the International Military Tribunal for the Far East ${ }^{61}$ convicted several Japanese military and political leaders based partly on evidence of inass rapes that occurred under their autliority. ${ }^{62}$ These trials also represent the first time rape was specifically identified as a war crime, ${ }^{63}$ and "commanders were lield responsible for rapes committed by soldiers under their command." The abduction and systematic raping of woinen during the war was determined to constitute inhuinane acts against the civilian population. ${ }^{65}$ The Tokyo Tribunal convicted several Japanese military commanders on charges of war atrocities whicl included rape ${ }^{66}$ and Japanese military inen were convicted for offenses committed against women who were forced to become "comfort woinen." 67 Because the defendants at the Tokyo Tribunal were not accorded the defense of liaving acted under superior orders, they could not "escape liability if, in obedience to a command, they commit[ed] acts which both violate[ed] unchallenged rules of warfare and outrage[ed] general sentiment of

60. Id. at $51-53$.

61. Charter of the International Military Tribunal for the Far East, Jan. 19, 1946, amended Apr. 26, 1946, T.I.A.S. No. 1589, reprinted in 4 Bevans, supra note 16, at 20 [hereinafter Tokyo Charter].

62. The Tokyo Tribunal found Japanese military and civil officials guilty of numerous war crimes, including rape. See JOHN A. APPLEMAN, MILITARY TRIBUNALS AND INTERNATIONAL CRIMES 259 (1971); INTERNATIONAL MILITARY TRIBUNAL FOR THE FAR EAST, Proceedings 4464-67, 4653 (Aug. 29, 1946). Admiral Soema Toyoda, former Commander-in-Chief of the Japanese combined fleet, was charged with violating the laws and customs of war because he permitted forces under his command to commit human rights abuses, including rape. He was later acquitted of these charges. William $\mathrm{H}$. Parks, Command Responsibility for War Crimes, MIL. L. REV., Fall 1973, at 1, 69-73.

63. 2 THE TOKYO JUdGEMENT: THE INT'L MILITARY TRIBUNAL FOR THE FAR EAST 965, 971-72, 988-89 (1977).

64. Swiss \& Giller, supra note 5 , at 613 (citations omitted).

Article 5 of the Charter of the International Military Tribunal of Tokyo defined war crimes as "violations of the laws or customs of war." Tokyo Charter, supra note 61, at 28. Article 5 of the Tokyo Charter also included crimes for which there was to be individual responsibility, including "[c]rimes against [h]umanity: [n]amely, murder, extermination, enslavement, deportation, and other inhumane acts committed before or during the war." Tokyo Charter, supra note 61 , at 28.

65. See supra note 62 .

66. INTERNATIONAL MiLITARY TRIBUnal FOR THE FAR EAST, JUdGMENT 1012, 1018-19, 1160-61, 1181, Annex A-6 at 113, 116-17 (1948).

67. WAR CRIMES ON Asian Women: Military SeXual Slavery by JaPan DuRING WORLD WAR II - THE CASE OF THE FILIPINO COMFORT WOMEN (Dan P. Calica \& Nelia Sancho eds., 1993). 
humanity." ${ }^{68}$ Thus, the Japanese soldiers who raped Korean and Filipino women were found guilty of committing war crimes and crimes against humanity, even though they claimed they were ordered to do so.

As this analysis shows, forced impregnation nuay be prosecuted as a war crime or a crime against humainty, and in sonie circumstances these regimes are the appropriate context in which to address forced impregnation. War crimes and crimes against humanity, however, do not specifically address crimes intended to destroy a group. Hence, these laws do not fully address forced impregnation as it is alleged to have occurred in the former Yugoslavia. When forced impregnation is committed with the intent to destroy a people, it is inore than a war crime or a crime against humanity-it is a crime of genocide. ${ }^{69}$

\section{FORCED IMPREGNATION IN THE FORMER YUGOSLAVIA}

The war in the former Yugoslavia had it roots in the decades following World War I, when the country was created, joining several ethnic groups under one state. ${ }^{70}$ Political changes after

68. Id. (citations omitted)

69. See infra notes 175-251 and accompanying text.

70. As a result of the Versailles self-determination principle, Yugoslavia was created in 1918. It joimed three South Slavic peoples, and was officially named the "Kingdom of Serbs, Croats, and Slovenes." Emmett B. Ford, The Legal System of Yugoslavia: Background, in 8 MODERN LEGAL SYSTEMS CYCLOPEDIA 8.210, 8.210.5, 8.210.9 (Kenneth R. Redden ed., 1991); see also JILL A. IRVINE, THE CROAT QUESTION 17 (1993). The creation of Yugoslavia united Slovenia, Dalmatia, Croatia, Bosnia-Herzegovina and the Vojvodina regions, formerly of the Austro-Hungarian Empire, with the pre-war Kingdoms of Serbia and Montenegro. See Ford, supra, at 8.210, 8.210.9. During the pre-war period Croatia, Slavonia and Vojvodina were part of the Hungarian part of the Hapsburg Empire, and Bosnia, Herzegovina, Slavonia and Dalmatia were part of the Austrian part of the Empire. See IRVINE, supra at 17. The Axis powers invaded and occupied parts of Yugoslavia during World War II. A fierce civil war ensued. See Ford, supra, at 8.210, 8.210.9. The Communists prevailed and, led by Tito, took power in 1946, proclaiming the Federal People's Republic of Yugoslavia. See id. at 8.210.10-11. It was later renamed the "Socialist Federal Republic of Yugoslavia" (SFRY), and it so renıined until the 1990-1991 break up. See id. The precise date of the commencement of the war is not particularly relevant to this Note. The International Tribunal for the Prosecution of Persons Responsible for Serious Violations of International Humanitarian Law Committed in the Territory of the Fonner Yugoslavia (ICTY) chose 1991 as the beginning of its tentporal jurisdiction. See Report of the Secretary-General Pursuant to Paragraph 2 of Security Council Resolution 808 (1993), U.N. SCOR, 48th Sess., at 16, U.N. Doc. S/25704 (1993). 
President Tito's death in 1980 led to the reemergence of virulent nationalism. The constitutional system collapsed in 1989, and Serbian nationalism found an outlet through the imposition of constitutional changes limiting the autonomy of the autonomous regions. ${ }^{71}$ Fueled by fears of Serbian hegennony and a continumg state of econoumic crisis, separatist tendencies flared in Slovema and Croatia. Rapidly mounting tensions over the future of the constitutional systein came to a head in 1991, and in July Slovenia and Croatia declared independence. War ensued between Croatia and Yugoslavia. Military action also occurred in Slovenia, but it was of limited scope and lasted only ten days. Hostilities reached a fragile, relatively peaceful ceasefire in January 1992. A inere two months later, Bosmia-Herzegovina declared independence. War broke out between Serbs, Croats and Muslims in Bosnia, and continued for four years.

Both during and since the war in the former Yugoslavia, allegations of forced impregnation as part of a larger policy of etlimic cleansing of Bosnia have arisen. ${ }^{72}$ Bosnian Muslim women claim that they were raped repeatedly until they became pregnant. ${ }^{73}$ In many cases, they were told that they would be forced to bear

The government underwent reorganization in the early 1970s, and the 1974 Constitution of the SFRY established a federal state of six republics: Bosnia-Herzegovina, Croatia, Macedonia, Montenegro, Slovenia, and Serbia. USTAV SociJALISTICKE FEDERATIVNE REPUBLIKE JUgOSLAVIJE (1974) [CONSTITUTION OF THE SOCIALIST FEDERAL REPUBLIC OF YUGOSLAVIA], art. 217, SLUŽBENI LIST, No. $9 / 74$ [hereinafter SFRY CONSTITUTION]. The two autonomous provinces of Vojvodina and Kosovo were within the Republic of Serbia. Under the 1974 Constitution, each of the nations of Yugoslavia had the "right to self-determination, including the right to secession," which was the inflammatory spark of the recent war. SFRY CONSTITUTION, supra.

71. See Ustav SaVezNe Republike JugoslaviJe [Constitution of the Federal REPUBLIC OF YUgosLAVIA], SLUŽBENI LIST SAVEZNE REPUBLIKE JUGOSLAVIJE (SRJ) [OFFICIAL GAZETTE OF THE FEDERAL RePUblic OF YugosLaVia] No. 1/92 (altering Part I of the former SFRY Constitution to remove language that ensured limited forms of self-government for the autonomous regions of Vojvodina and Kosovo).

72. See, e.g., No Justice, No Peace: Accountability for Rape and Gender Based Violence in the Former Yugoslavia, 5 HASTINGS WOMEN'S L.J. 91 (1994); 2 WAR CRIMES IN BOSNIA-HERCEGOVINA, supra note 6, at 21-23; Tadeusz Mazowiecki, Special Rapporteur of the Commission on Human Rights, Report on the Situation of Human Rights in the Former Yugoslavia, U.N. Economic and Social Council, 49th Sess., Agenda Item 27, at 19, U.N. Doc. E/CN.4/1993/50 (1993); The European Community Investigative Mission into the Treatment of Muslim Women in the Former Yugoslavia, Report to European Community Foreign Ministers, supra note 4, at 4-7; AMNESTY INTERNATIONAL, BOSNIAHERzegovina: RAPE AND SEXUAl ABUSE by ARMed Forces (1993); MARK AlmoNd, EUROPE'S BACKYARD WAR 269-70 (1994).

73. See infra notes $87-123$ and accompanying text. 
Serbian children. ${ }^{74}$ After they became pregnant they were held captive until it was too late to have an abortion. ${ }^{75}$ Although forced impregnation is a crime distinct from rape ${ }^{76}$ much of the evidence that there was a Serb pohicy of forced impregnation is linked to the perpetration of mass rape. Hence, a discussion of forced impregnation in the Yugoslav conflict necessarily includes a discussion of the claims of systematic rapes $i m$ the former Yugoslavia.

\section{A. Ethnic Cleansing}

All parties to the conflict in the former Yugoslavia are guilty of war crimes, but to varying degrees. The Serbs were the aggressors $\mathrm{m}$ the war $^{77}$ and as such were in a position to commit serious violations of international humamitarian law. ${ }^{78}$ Soldiers on all sides committed many violations of imternational humamitarian law, sometiunes in the pursuit of the objective of forced displacement of civilians, but investigatory reports indicate that on the whole the chief offenders were the Bosnian Serbian military and paramilitary forces." "In most Serbian-held areas of Bosnia, abuses agamst non-Serbs [were] the result of a pre-meditated plan by local and regional civilian, military and/or pohice authorities." 80 Abuses by Bosnian Croats and Bosmian Muslims, ${ }^{81}$ in contrast, appear to have been perpetrated by imdividuals, and not as part of a larger plan or policy. ${ }^{82}$

Crimes committed by Serbs follow a recognizable pattern that has come to be known as "ethnic cleansing." 83 Ethnic cleansing is

74. See infra notes $108-11$ and accompanying text.

75. See infra notes $112-23$ and accompanying text.

76. See supra note 6.

77. See 2 WAR CRIMES IN BOSNIA-HERCEGOVINA, supra note 6 .

78. See id. at 8-9.

79. Helsinki Watch, an impartial investigator, reports that "[a]lthough all sides have committed serious abuses [our] findings indicate that the most severe and overwhelming number of crimes have been committed by Serbian forces." Id. at 1 .

80. Id. at 8 .

81. See Stephen Schwartz, Rape as a Weapon of War in the Former Yugoslavia, 5 HAstings WOMEN's L.J. 69 (1994) (suggesting that Muslims and Croats are not innocent of violations of imtemational humanitarian law).

82. 2 WAR CRIMES IN BOSNIA-HERCEGOVINA, supra note 6, at 7. For imformation on abuses perpetrated by Bosnian Croat and Muslim forces, see Ivana Nizich, Violations of the Rules of War by Bosnian Croat and Muslim Forces in Bosnia-Herzegovina, 5 HASTINGS WOMEN'S L.J. 25 (1994).

83. See 2 WAR CRIMES IN BOSNIA-HERCEGOVINA, supra note 6, at 8-9. The term 
the Serbian pohicy of removing or exterminating all non-Serbs in the territory under Serbian control. Abuses against the Mushim population were perpetrated by imdividual soldiers or whole units of military, paramilitary, or police forces. ${ }^{84}$ The way in which the ethnic cleansing was carried out imdicates that the perpetrators did not fear punishment for their acts:

The public nature of the abuses, and the frequency with which they take place indicates that individual soldiers and inilitary units do not anticipate disciplinary actions by their superiors. The lack of punishment of Serbian soldiers for these abuses implies coniplicity on the part of the civilian, military and police authorities of the self-proclained "Serbian Republic" (Republika Srpska). Helsinki Watcli is not aware of any case in which Serbian forces guilty of abuses liave been punished by their superiors for their crimes. ${ }^{85}$

In October 1992 Tadeusz Mazowiecki, the Special Rapporteur appointed by the Umited Nations Commission on Human Rights, concluded that ethmic cleansing was "a goal of the war, not a consequence." ${ }^{86}$ In its most general form, the primary aim of the Serbian forces and the policy of ethnic cleansing was to capture and consolidate territory by forcibly displacing or killing non-Serbs in the area. But ethnic cleansing did not only involve the forced displacement and murder of civilians. Rape and forced impregnation were another part of this policy of ethnic cleansing.

\section{B. Rape and Forced Impregnation}

The use of rape and forced impregnation to achieve ethnic cleansing made rape into a weapon of war. ${ }^{87}$ Rape in the former Yugoslavia has been characterized by the Special Rapporteur as an instrument of war and as a niethod of ethnic cleansing "intended to humiliate, shame, degrade and terrify the entire ethnic group." 88 Preliminary evidence indicates that Serbs used rape

\footnotetext{
"ethnic cleansing" originates from the Serbian/Croatian word "rašišenje," literally "cleansing," "clearing," or "dispersing." SRPSKOHRVATSKO-ENGLESK1 REČNIK [SERBOCROATIAN-ENGLISH DICTIONARY] 518 (3d ed. 1990).

84. 2 WAR CRIMES IN BOSNIA-HeRCEgovina, supra note 6 , at 8.

85. Id. at 9.

86. Miron REZUN, EUROPE AND WAR IN THE BaLKANS 161 (1995).

87. See Sabrina Petra Ramet, Balkan Babel 129 (2d ed. 1996).

88. Mazowiecki, supra note 72 , at 19.
} 
throughout Bosnia as a way of terrorizing Muslims into leaving certain areas, thereby carrying out the policy of ethnic cleansing. ${ }^{89}$ At a congressional hearing of the Commission on Security and Cooperation in Europe Regarding the Refugee Crisis and War Crimes in the Former Yugoslavia, ${ }^{90}$ Catherme O'Neill, Chairwonlan of the Wonren's Commission on Refugee Woinen and Children, ${ }^{91}$ testified that "[t]he goal of the Serbian forces . . . is to niove out the wonien and the children." $" 92$

Furthermore, numerous reports indicate that rape was used not only as a form of terror and violence in and of itself, but also as the ineans of forcibly impregnating Bosnian Muslim woinen. ${ }^{93}$ Women appear to have been raped by the thousands ${ }^{94}$ and rapes were undeniably committed by all sides against all sides. Serbs, however, appear to have committed the overwhelming niajority of rapes in Bosnia, ${ }^{95}$ and only Serbs appear to have used rape as a

89. See RAMET, supra note 87, at 258; DAVIE RIEFF, SLAUGHTERHouse 121 (1995).

90. Hearing of the Commission on Security and Cooperation in Europe Regarding the Refugee Crisis and War Crimes in the Former Yugoslavia, 103d Cong. (1993).

91. The Commission was actively involved in investigating and seeking treatment for the systennatic rape and forced impregnation of Bosnian wonien and girls; it sent a delegation of American women to Croatia and Bosnia to talk with refugee wornen. See id.

92. Id. (statement of Catherine O'Neill, Chairwonan of the Women's Commission on Refugee Women and Children, before the Commission on Security and Cooperation in Europe, Jan. 25, 1993).

93. A horrific feature of the Bosnian war was "the incidence of organized systematic rape-or rather, forced impregnation, since pregnancy was a conscious goal of the Serbs." RAMET, supra note 87 , at 258.

94. See supra note 4; Final Report of the Commission of Experts Established Pursuant to Security Council Resolution 780, 49th Sess., Annex, U.N. Doc. S/1994/674, at 55-60 (1994) [hereinafter Final Report]; GUTMAN, supra note 8, at 64. "An estimated 20,000-50,000 Bosnian Muslim women had been raped by Bosnian Serb soldiers in a systematic campaign of humiliation and psychological terror." RAMET, supra note 87, at 267, 284 (citing Drakulić, supra note 4, at 116, 118).

Although numerous allegations of forced inipregnation have been made and documented, conclusive data from investigative reports is currently unavailable. On behalf of the U.N. Human Rights Commission, a team of experts visited six major medical centers in Zagreb, Sarajevo, Zenica and Belgrade during January of 1993. Report of the Team of Experts on Their Mission to Investigate Allegations of Rape in the Former Yugoslavia from January 12-23, 1993, U.N. SCOR, 48th Sess., Annex II, U.N. Doc. S/25341 (1993). The team identified 119 pregnancies as a result of rape in 1992. Id. at 65. The team concluded that "[i]t is not possible to know precisely the actual number of rapes or the number of pregnancies due to rape that have occurred ... [nonetheless] the incidence of rape in the confiict . . . has been widespread." Id. at 68-69. The Report noted that the number of pregnancies reported should be seen as a minimum because the eniotional pain and stigma associated with rape have likely caused under-reporting. See $i d$. at 68 .

95. A CIA Report on ethnic cleansing in Bosnia asserts that the Serbs carried out 
weapon of war to achieve military objectives. ${ }^{96}$ It was "massive, organized and systematic, ${ }^{, 97}$ and allegedly was used as a planned and deliberated strategy to terrorize members of an innocent civilian population. ${ }^{98}$ Many reports state that the perpetrators of rape told their victims that they were ordered to rape them as part of the military campaign to keep the victims and their families from ever returning to the region. ${ }^{99}$ After imvestigating numerous reports of widespread and systematic rape and forced impregnation, the Final Report of the Commission of Experts Established Pursuant to Security Council Resolution 780 (Final Report) concluded that the rapes "seem to be a part of an overall pattern."100

[The rapes] do not appear to be random, and they indicate at least a policy of encouraging rape supported by the deliberate failure of camp commanders and local authorities to exercise command and control over the personnel under their authority. These patterns strongly suggest that a systematic rape policy existed... [and] that some level of organization and group activity was required to carry out many of the alleged rapes. ${ }^{101}$

Regarding the use of rape in order to forcibly impregnate Bosman Muslim women, the Final Report found that "[s]oine captors also state that they are trying to impregnate the women. Pregnant

$90 \%$ of the acts of ethnic cleansing, including rape, in Bosnia. See Roger Cohen, CIA Report on Bosnia Blames Serbs for 90\% of the War Crimes, N.Y. TimES, Mar. 9, 1995, at A1; see also Final Report, supra note 94, at 60 (finding that the largest number of reported victims have been Bosnian Muslims, and the largest number of alleged perpetrators have been Bosnian Serbs); 2 WAR CRIMES IN BOSNIA-HERCEGOVINA, supra note 6, at 7-9 (stating that Serbian forces, in pursuit of the goal of "ethnic cleansing," were responsible for many violations of human rights and humanitarian law, including rape).

96. See Yolanda S. Wu, Genocidal Rape in Bosnia: Redress in United States Courts under the Alien Tort Claims Act, 4 UCLA WOMEN's L.J. 101 (1993) (citing 2 WAR CRIMES IN BOSNIA-HERCEGOVINA, supra note 6, at 10); see also Rape Was Weapon of Serbs, U.N. Says, N.Y. TIMES, Oct. 20, 1993, at A1 (reporting that the United Nations War Crimes Commission, which has collected reports of 3,000 rape cases and identified 800 of those victims by name, found that "although Serbian, Croatian and Mushim forces all committed rapes, most victims were Muslims and most alleged perpetrators were Serbs.").

97. S.C. Res. 820, U.N. SCOR, 48th Sess. at 8, U.N. Doc. S/INF/49 (1993).

98. See Dennis DeConcini, Enforce No-Fly Zone in Bosnia, USA TODAY, Jan. 28, 1993, at 13A (claiming that his personal interviews with Bosnian Muslims indicate a defimite pattern of mass rape).

99. See Final Report, supra note 94, at 59.

100. Id. at $55-60$.

101. Id. 
women are detained until it is too late for them to obtain an abortion."102 International media repeatedly reported the existence of detention camps in which women were held and systematically raped as part of ethnic cleansing. ${ }^{103}$ Many victims indicated that they were told that a policy of rape existed and that their rapists imtended to impregnate them. One rape victim reported that the soldier who assaulted her told her: "We have orders to rape the girls." ${ }^{104}$ Another young woman said her captors told her that "they wanted to 'plant the seed of Serbs in Bosma." "105 Yet another woman was detamed by her Serb neighbor (who was a soldier) in her village for six months. She reported that she was raped almost daily by three or four soldiers and that she was told that she would give birth to a "chetnik"106 boy who would kill Muslims when he grew up. Her rapists repeatedly said that their President had ordered them to do this. ${ }^{107}$

A woinan detamed in the Omarska detention camp told investigators: "When I was assaulted, [t] hey said I was an Ustasha ${ }^{108}$ and that I needed to give birth to a Serb-that I would then be different." $" 109$ Another woman recounted the experience of her forced impregnation: " $[\mathrm{I}] \mathrm{t}$ was their aim to make a baby. They wanted to humiliate us. They would say directly, looking into your eyes, that they wanted to make a baby. They seemed to be men

102. Id. at 59.

103. See, e.g., GuTMan, supra note 8, at 64; John F. Bums, Muslims Say Serbs Raped Them in Bosnia, N.Y. TMES, Oct. 3, 1992, § 1, at 5; Jon Margolis, Consequences of Failure in Bosnia, CHI. TRIB., Dec. 22, 1992, at 21; Rachael N. Pine, Women and War: Double Jeopardy, USA TODAY, Oct. 7, 1992, at 13A; Ricchiardi, supra note 12, at 1B; Serbs' Rape of Muslim Women in Bosnia Seen As Tactic of War, Houst. CHRON., Aug. 13, 1992, at A1.

104. Final Report, supra note 94, at 59.

105. Id. at 76 .

106. Chetniks were members of a Serbian nationalist military group in World War II. See Ivo Banac, THE NATIONAL QUESTION IN Yugoslavia 195, 377 (1984). In the current conflict nationalist Serbs are often labeled "chetniks." MISHA GLENNY, THE FALL OF YUGOSLAVIA 83 (1993).

107. See Final Report, supra note 94, at 59. According to several accounts, rape victims reported that their assailants shouted "you will have a Serbian child!" Mazowieki, supra note 72, at 69; see also European Community Investigative Mission into the Treatment of Muslim Women in the Former Yugoslavia, supra note 4, at 5 (affirming that, in many cases, the rape of Muslim woinen was intended to result in pregnancy).

108. "Ustasha" is a term for a Croatian nationalist who, during WWII, supported the Nazi puppet regime in Croatia. See IRVINE, supra note 70, at 50.

109. 2 WAR CRIMES IN BOSNIA-HERCEGOVINA, supra note 6 , at 164 (quoting a woinan in the Oinarska detention camp). 
without souls and hearts. They are without mercy."110 Women from the Obudovac camp reported:

"A gynecologist would come to the hall, to one of the classrooms. ... Only the younger women would see the doctor. I think they were checking to see if we were pregnant because he would say, 'You're not pregnant.' The Serbs said to us, 'Why aren't you pregnant?' ... They wanted women to have children to stigmatize us forever."111

A research scholar at the University of Michigan and chronicler of sexual atrocities committed by Serbs also reported hearing of women who had been raped "at least 10 times a day for 21 days or until impregnated and then being held too long for a safe abortion."112 The first victims of multiple rape and detentionafter- conception arrived in Zagreb in the spring of 1992, bearing tales of rape camps and detention. ${ }^{113} \mathrm{~A}$ woinan from Rogotica reported: "'I was violated [by Serbian soldiers] at least once every other night on average, for a number of weeks. . . . I became pregnant quite soon." "114 Often wonien were held as prisoners until they reached term, and then were released so as to give birth to illegitimate Serb babies. ${ }^{115}$ During September 1992 over 150 Muslim women and girls crossed into government held areas of Sarajevo in the advanced stages of pregnancy, claiming that they became pregnant after being raped by Serbian nationahist fighters and that they were then held captive for months in an attempt to keep them from having abortions. ${ }^{116}$ Women interviewed by Helsinki Watch and the Woinen's Rights Project "described how they were gang raped, taunted with ethnic slurs and cursed by rapists who stated their intention to forcibly impregnate women."117

110. Id. at 215 .

111. Id. at 218-19.

112. Casey Selix, Witness; Meet Natalie Nenadic, a 26-year-old Michigan Scholar Whose Life Has Become Forever Intertwined with the Fate of Woman in Far-Off Croatia and Bosnia, DALlas MORNING NEwS, Apr. 21, 1993, at 5C (describing work of Natalie Nenadic).

113. The women arrived in Zagreb in the advanced stages of pregnancy. Many of these woinen either aborted or gave their babies away for adoption. See ED VULLIAMY, SEASONS IN HELL 196 (1994).

114. Id. at 198.

115. REZUN, supra note 86 , at 161 .

116. Burns, supra note $103, \S 1$, at 5 .

117. 2 WAR CRIMES IN BOSNIA-HERCEGOVINA, supra note 6 , at 21 . It is unclear how inany women have been forced to bear children because of rape. As of January 13, 1993, 
In addition to terrorizing Muslims into leaving Serb-occupied areas, Serb soldiers also allegedly raped women to "destroy[] [the women's] possibility of reproducing within and 'for' their commumity." ing Serbs" after they became pregnant. ${ }^{119}$ The Final Report presents evidence that "[p]erpetrators tell female victims that they will bear children of the perpetrator's ethnicity, that they must become pregnant, and then hold them in custody until it is too late for the victims to get an abortion..120 One victim, seventeen-year-old Marianna, was raped by guards in a Serbian detention camp as many as ten times a day. She was repeatedly told, "Now you will have Serbian babies for the rest of your life."121 A fifteen yearold said that she was raped by "chetnik" irregular paramilitaries from Serbia and Bosnia and that she and other victims were told they would be forced to bear "chetnik" children. ${ }^{122}$ Mahir Zisko, executive director of the Bosnian Government war-crimes commission, reported that "[w]e are seeing the same pattern repeatedly, of Chetniks telling these women, 'It is better to give birth to Clietniks than to Muslim filth,'... [and] '[w]lien we let you go hoine you'll have to give birth to a Chetnik. We won't let you go while you can have an abortion." "123

\section{UNDERSTANDING FORCED IMPREGNATION IN THE CONTEXT OF THE FORMER YUGOSLAVIA}

The apparent policy of forced impregnation in Yugoslavia can be better understood in light of the complex ethnic and religious history of the region. This context explains why a Serb would see

Dr. Veseljko Grizelj, director of the Petrova Hospital in Zagreb, knew of five women pregnant consequent to rape who had been treated at his hospital. See id. at 21-22, n.13. Dr Miomir Krstic, director of the family planning and childbirth division of the GAK Clinical Center in Belgrade, stated that he knew of four women pregnant consequent to rape in Bosnia. See id.

118. Rhonda Copelon, Surfacing Gender: Re-Engraving Crimes Against Women in Humanitarian Law, 5 HASTINGS WOMEN'S L.J. 243, 261 (1994).

119. VullamY, supra note 113, at 199; see also Ricchiardi, supra note 12, at $1 \mathrm{~B}$ (describing similar statenrents nrade by victims of repeated rape).

120. Final Report, supra note 94, at 59-60.

121. Pine, supra note 103 , at $13 \mathrm{~A}$.

122. Burns, supra note $103, \S 1$, at 5 .

123. Id: see also European Community Investigative Mission into the Treatment of Muslim Women in the Former Yugoslavia, supra note 4123.12

, at 5 (finding deliberate impregnation to be a primary motive of rapes). 
the offspring of forced impregnation as Serbs and how a program of forced impregnation can be genocide.

The history of Serbs and Muslims distinguishes the Yugoslav battlefield from the persecution of Jews by the Nazis in World War II. For Serbs and Muslims, unlike Jews, the ethnicity of the father is decisive in determining the ethnicity of the child. ${ }^{124}$ It is thus logical for a Serb to beheve that a Bosnian Muslim woman impregnated with his child would bear a Serb baby. Sonie authors also have argued that rape and forced impregnation are a response to historical domination of the Serbs by Muslim land owners. ${ }^{125}$ In this inaimer Serb men could take their revenge on the Muslims by defiling their woinen. ${ }^{126}$ "Defiling Muslim woinen struck at the whole idea of a separate Muslim Cominunity. In the eyes of Serbs they were renegades and their woinbs ought to bear Serbs not 'Muslims."'127

Ethnicity and the meaning of the word "nation," or narod, have special import in the foriner Yugoslavia. ${ }^{128}$ The South Slav lands of the Balkan peninsula are one of the inost ethnically, linguistically and religiously coniplex areas of the world. ${ }^{129}$ Of all the countries in Europe, the former Yugoslavia was by far the least homogenous. ${ }^{130}$

Bosnia was an independent kingdom in inedieval times. ${ }^{131}$ The region developed a distinct character under Ottonian occupation, during which a large number of the population converted to Islam. ${ }^{132}$ However, these Muslims did not at this time possess a

124. See RIEF, supra note 89 , at 107.

125. See, e.g., ALMOND, supra note 72, at 269-70.

126. See id.

127. Id. at 270.

128. The Serbian/Croatian word "narod" means "people," "nation," or "ethnic group." SRPSKOHRVATSKO-ENGLESKI REČNIK [Serbocroatian-English Dictionary] 308 (3d ed. 1990).

129. See Hugh Poulton, THE Balkans, MiNORITIES AND STATES IN CONFLICT 41 (1993).

130. See id. Poulton writes:

The area of Bosnia-Hercegovina was the scene of many of the worst atrocities committed during the civil war in World War II, and the ethnic mix of Orthodox Serbs, Catholic Croats and Muslim Slavs has historically been an explosive Id. one with both Serbia and Croatia claiming the territory for their own.

131. See FERDINAND SCHEVIII, A History OF THE BALKANS 202-03 (1991).

132. Islam came to Bosnia as a result of the Ottoman Turkish conquest in the late fourteenth to early sixteenth centuries. The spread of Islam to the South Slavic peoples was through conversion by Turkish occupiers, rather than through immigration of other Islamic peoples from other regions of the Ottoman empire. See STEVEN L. BURG, THE 
distinct "national" identity. ${ }^{133}$ The development of a separate nationality was a cumulative process beginning with conversion in the fourteenth century and culminating with national recognition of the Muslims as a "nation" of Yugoslavia in 1968.

Throughout the nineteenth and twentieth centuries, Serbs argued that Muslims were really Serbs, except for their religion. ${ }^{134}$ This idea of national oneness, narodno jedinstvo-that the Serbs, Croats and Slovenes were three tribes of one Yugoslav nation-developed under the unitary vision of a South Slav state arising from an expanded Serbian Kingdom. ${ }^{135}$ The proponents of this idea of national oneness, primarily Serbs, believed that all differences between South Slavs were non-organic, that they were one people, differentiated into different groups by religion or culture. This behef led naturally to the idea that these differences could be overcome. For example, the linguist Vuk Karadžić, who devised the standard orthography for the Serbo-Croatian language, argued that anyone speaking the Stokavian dialect of SerboCroatian was a Serb, "thus broadening the definition of the Serb nation to include stokavian-speaking Catholic Croats and Bosnian Muslims." ${ }^{3136}$ Serbian adherents to the concept of national unity were and are eager to retrieve their brethren across the border. ${ }^{137}$ "Thus, language and religion were the essential, though occasionally contradictory, elements of the Serb national ideolo-

Polmtical integration of Yugoslavia's Muslims: Determinants of Success and Fallure 2 (The Carl Beck Papers in Russian and East European Studies No. 203, 1983); IRVINE, supra note 68 at 20-21; see also PETER MAASS, LOVE THY NEIGHBOR 27 (1996) (supporting the same proposition). "Both Western and Yugoslav historians have generally agreed that the adherents of the Bosnian church converted to Islam en masse, providing the bulk of the early Islamic population." BURG, supra, at 2 (emphasis omitted). Some scholars assert that the conversion was accomplished primarily as a single act, converting over 36,000 families at once. See, e.g., Vatro MURVAR, Nation AND RELIGION IN CENTRAL Europe and tHe Western Balkans-The Muslims in BosNia, HERCEGOVINA AND SANDŽAK: A SOCTOLOGICAL. ANALYSIS 11-14 (1989). Others assert that it was a more gradual process, resulting from increasing urbanization and expansion of trade throughout the Empire which brought the masses into contact with cities where Islam was strongest. See, e.g., BURG, supra, at 3.

133. One of the first expressions of the Muslims as a "nation" was the establishment of the Muslimanska Narodna Organizacija [Muslim National Organization] (MNO), in 1906. See BURG, supra note 132, at 21 \& n.12.

134. See NOEL MALCOLM, BOSNIA: A SHORT HISTORY xxiii (1994).

135. See IRVINE, supra note 70 , at 27.

136. Id. at 28-29. See BANAC, supra note 106, at 80 (describing Karadžić's linguistic Serbianism).

137. See IRVINE, supra note 70 , at 30. 
gy."138 Because the language and literary culture of the majority of the Bosnian Muslim population was Serbo-Croatian, ${ }^{139}$ rehion became the primary differentiation among the Yugoslavs. ${ }^{140}$

In the modern era, religion continues to divide the Yugoslav peoples. It played a large role in the former Yugoslavia, even under a socialist state officially committed to a doctrine of atheisn. ${ }^{141}$ The territory of the former Yugoslavia, once the liome of the Bogumil lieresy, ${ }^{142}$ lies at the intersection of Ronian Catholicism, Orthodoxy and Islam. Serbs are generally Eastern (or Serbian) Orthodox, and Croats are generally Roman Catholic. Bosnian Croats and Bosnian Serbs follow suit. The Orthodox church annong Serbs is the closest to a "state" church, and the Croatian postWorld War II nationalist movement strongly identifies with the Vatican. ${ }^{143}$

This religious division of the Yugoslav society was reinforced by the political character of the Yugoslav state. ${ }^{144}$ A close correspondence between religion and nationality developed as the political tide in Yugoslavia swung back and forth between a pressure to assimilate and a pressure to define the groups as separate nationalities. $^{145}$ At one time, the Austrians, after the transfer of Bosnia-Herzegovina from the Ottoman Empire to the Austro-Hungarian Enıire, tried to counteract Serb and Croat nationahist movements by creating a territorially-based Bosnian national identity. That identity never fully developed, however, and the "Bosnian population renamed divided into distinct ethno-national communities that were defined in large part by religion." 146 Later, during a period of nationalist assertion under Austrian rule, Muslim self-identification took on a more national character. ${ }^{147}$

\footnotetext{
138. Id. at 29.

139. See BURG, supra note 132 , at 4 .

140. See id.

141. See GlenNY, supra note 106 , at 140 .

142. The development of an independent Bosnian Christian Church, Crkva Bosanska, in Northern Herzegovina is commonly referred to as the Bogumil Heresay. See MURVAR, supra note 132 , at 5-10.

143. See IRVINE, supra note 70 , at $236-41$.

144. See BURG, supra note 132, at 12-13.

145. See id. at 13; GLENNY, supra note 106 , at 142.

146. BURG, supra note 132 , at $7-8$.

147. See id. at 12.
} 
Although Muslims came under much pressure during the 1920s and 1930s to declare themselves Serbs, ${ }^{148}$ after World War II they were left to occupy a nebulous undefined category in the eyes of the Yugoslav state. The Muslims in Bosnia often answered in the national censuses that they were "undecided Muslim[s]" or "undetermined Yugoslavs." 149 "Thus, 'Muslimness' in Bosnia seemed to be coincident with national separateness; but not with any category of nationahty then available." ${ }^{.150}$ On the other hand, in other parts of Yugoslavia, this "Muslimness" did not preclude identification with another nationality. The majority of Muslims in Croatia, Serbia and Macedonia identified themselves as Croats, Serbs and Macedonians of the Islamic faith. ${ }^{151}$

During his reign, Tito attempted to quash national tensions between Serbs and Croats with a game of divide and conquer. ${ }^{152}$ $\mathrm{He}$ attempted to raise the position of Bosnia-Herzegovina by declaring the Muslims to be a nation, ${ }^{153}$ and he extended national status to the Muslims when it appeared that inter-national conflict would tear apart Yugoslav society. ${ }^{154}$ Recognition of the Muslims as a distinct group began with the 1961 census, when the authorities accepted "Muslim" as an "ethnic" but not "national" category. ${ }^{155}$ Official recognition of Muslims as a separate "nation," as opposed to only as an "ethnic group," came with the adoption of the new Bosnian Constitution in 1963. ${ }^{156}$ The new Bosnian Constitution made "Muslim" a national category equal to "Serb" and "Croat." The final, official Yugoslav assertion that "Muslim" denoted a separate nationality came in 1968. A communique of the ineeting of the Bosnian Central Committee in May 1968 stated: "It has been shown, and present socialist practice confirms, that the Muslims are a distinct nation."158 This recognition was reflected in the 1971 and 1981 censuses, in which "Muslim" was an

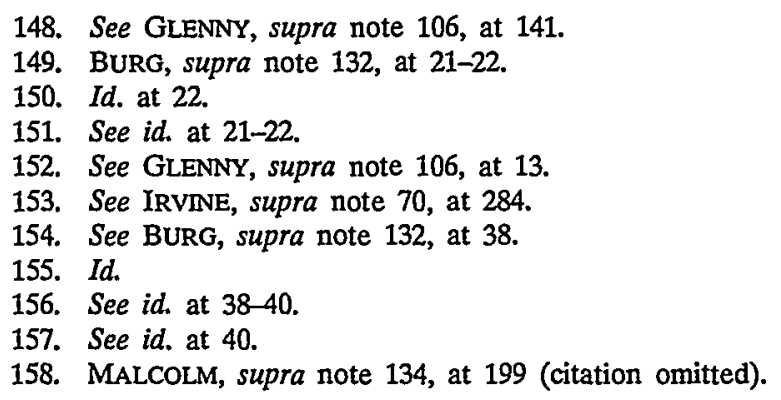


independent choice under the category of nationality. ${ }^{159}$ After 1971, Muslims were officially recognized as a distinct Yugoslav narod comprising about $9 \%$ of the total Yugoslav population. ${ }^{160}$

Because of its political and religious history, the former Yugoslavia had a multi-national federation with a three-tier system of national riglits as follows:

(i) the Nations of Yugoslavia, each with a national home based in one of the republics. There were six officially recognized "Nations of Yugoslavia": Croats, Macedonians, Montenegrins, Muslims, Serbs and Slovenes; ${ }^{161}$

(ii) the Nationalities of Yugoslavia, which were legally allowed a variety of language and cultural rights. There were 10 etlinic groups officially recognized as "Nationalities." The largest were the Albanians and the Hungarians concentrated in Kosovo and the Vojvodina, respectively; the others were the Bulgarians, Czechs, Gypsies, Italians, Romanians, Ruthenians, Slovaks and Turks; ${ }^{162}$

(iii) Other Nationalities and Ethnic Groups, which are the remaining ethnic groups - Austrians, Greeks, Jews, Germans, Poles, Russians, Ukrainians, Vlalıs and others including those who classified themselves as "Yugoslavs."163

Hence, the attributive adjective "Bosnian" merely designates a republic from which one comes, and is not an ethnic identifier. ${ }^{164}$ The Mushinis in the former Yugoslavia are a unique group. They are one of the only nations in the world to be defined solely by their confessional. Within Bosnia-Herzegovina, the Muslims are the largest single group, comprising about $40 \%$ of the population. ${ }^{165}$

In large part, the stage for the war in the former Yugoslavia was set by the word "nation." The first line of the 1974 Yugoslav Constitution announced "the right of every nation to self-determination, including the right to secession," 166 but the right was thought to be held by the "nations"-narodi-of Yugoslavia, ethni-

159. See BURG, supra note 132 , at 48 .

160. See Poulton, supra note 129 , at 39.

161. See id. at 5 .

162. See id.

163. See id.

164. Likewise, there are "Serbian Croats" and "Croatian Serbs." The attributive adjective designates the place of residence and the noun designates ethnic affiliation.

165. See Poulton, supra note 129 , at 39.

166. UstaV SAVEzNE REPUBLIKE JugoslaViJe [CONSTITUTION OF THE FEDERAL REPUBlic of YugosLavia], Službeni list Savezne Republike Jugoslavije [Official Gazette of the Federal Republic of Yugoslavia] [Sluzbeni list SRJ] No. 1/92. 
cally defined, and not by the republics. Althougl these nations were recognized as having their several republics, it was the nations, not the republics, that were described as having united to form the Yugoslav state. ${ }^{167}$ The republics therefore did not possess the riglit to secede. ${ }^{168}$ "This seemingly arcane distinction between 'nation' and 'republic' as the bearer of riglits was actually of vital political importance. The essence of the separate nationalist political movements in Yugoslavia after 1989 was to assert the need for 'nation,' ethnically defined, and 'state' to coincide."169

This religious and political history demonstrates that in every Bosmian Muslim one also can find a South Slav-a Serb or a Croat or, more likely, a mix thereof. In fact, to even specify this identity as Serb or Croat would be wrong, because no distinct Serb or Croat identities existed in Bosnia before Islamization. ${ }^{170}$ When these identities did begin to coalesce, it was on the basis of religion, not on the basis of an inherent differentiation between Serbs and Croats. For centuries the language, history and geographic location of these two peoples indicated that they had been members of the same group. ${ }^{171}$ Thus, in essence, if one looks beyond the religion of all three groups-Serbs, Croats and Mushinis-one finds a Soutli Slav. This is evidenced in today's terminology: Bosnian Muslims, Bosnian Serbs and Bosnian Croats. "Bosnian" is more tlian a territorial designation; it signifies the common South Slav background of the people.

A policy of forced impregnation as a means of genocide is quite plausible in the context of this common background. ${ }^{172} \mathrm{~A}$

\footnotetext{
167. See id.

168. See id.

169. Robert M. Hayden, The Bosnian Debacle, in THE DIPLOMATIC RECORD 1992-1993, at 5, 7 (Allan E. Goodman ed., 1995).

170. See supra note 132 and accompanying text.

171. See MALCOLM, supra note 134, at 7-12.

172. Comparison between Nazi policy during World War II and the Serbs in the former Yugoslavia illustrates the unique situation in the former Yugoslavia. Germans considered themselves ethnically distinct from the Jews. See Daniel J. GoldHaGen, HITLER's WILLING EXECUTIONERS 81 (1996) (noting that "the prevailing German conception of the Jews posited them to be a race inexorably alien to the Germanic race"). A policy of rape would have been in direct conflict with Nazi philosophy and policy. $C f$. TELFORD TAYLOR, THE ANatomy OF tHE NUREMBerg Trials 21 (1992) (discussing the German miscegenation laws); GOLDHAGEN, supra, at 117 (noting that Germans complied with miscegenation laws regarding Jews while ignoring to some degree the same restrictions for non-Jewish foreigners). Miscegenation laws were in place to prevent the mixing of the races:
} 
Bosmian Muslim woman may be looked upon as perhaps inferior, but not as ethnically different. Children from her womb would be regarded as South Slavs-either Serb, Croat or some mix thereof. Hence, a Serb pohicy of forced impregnation could logically exist. The anecdotal evidence available so far suggests that such a policy might have existed. ${ }^{173}$ If the policy did exist, the remaining question is whether forced impregnation should be treated as a crime of genocide defined by the Genocide Convention of $1948 .{ }^{174}$

\section{FORCED IMPREGNATION AS A CRIME OF GENOCIDE}

Genocide is the gravest crime known to mankind. In response to the mass extermination of the Jews during World War II, the United Nations sponsored a treaty that pledges its signatories to prevent and suppress genocide. ${ }^{175}$ Fifty years later, a new convulsion of genocide appears to have gripped a European people, with forced impregnation as one of the tools of this destruction. Although forced impregnation is a clear violation of international humanitarian law, ${ }^{176}$ the criminal definitions of a war crime, a grave breach or crimes against humamity do not encompass the concept of destroying a group. This is addressed by the Genocide Convention. ${ }^{177}$

If, as the evidence seems to indicate, a pohicy of forced impregnation was used to try to destroy the Bosnian Muslim people, then the policy is a crime of genocide. ${ }^{178}$ When reproduction is

Technically it was verboten for a German to rape a Jew under the stern prohibition against 'race defilement'-the injunction against contaminating Aryan 'blood' contained in the Nuremberg race laws of 1935 that extended under its own twisted logic to forcible intercourse as well as to marriage or extramarital liaison.

BROWNMILlER, supra note 1 , at $46-47$. That is not to say that rape did not occur. However, Jewish wonen alone did not suffer rape as the German army advanced into Russia; "all wonien were prey." Id. at 50-51. This historical evidence negates assertions of a concerted Nazi policy of rape only against Jewish women during World War II. Rather it might be taken as evidence of lack of a concerted policy to use rape as modus vivendi for the propagation of the victor's race. See id. at 51 .

173.' See supra Part II.

174. See Genocide Convention, supra note 9.

175. See id.

176. See supra text accompanying notes 70-123.

177. See Genocide Convention, supra note 9.

178. Selma Hecimovic of the Center for rape victims in Zenica reports: "This has gone further than a 'war crime,' this is not a war crime any nore but an attempt to de- 
used to proliferate members of one group and simultaneously to prevent the reproduction of members of another, it is a form of destruction. When forced impregnation is carried out on a mass, systematic basis, for the purposes of "destroying the family life of the victims ... for cleansing the vicinity of all other ethnicities,"179 and producing babies of the conquering group, it becomes genocidal.

\section{A. Forced Impregnation under the Genocide Convention}

The crime of genocide is defined in Article II of the Genocide Convention:

In the present Convention, genocide means any of the following acts committed with intent to destroy, in whole or in part, a national, ethnical, racial, or rehgious group, as such:

(a) Killing members of the group;

(b) Causing serious bodily or mental harm to members of the group;

(c) Deliberately inflicting on the group conditions of life calculated to bring about its physical destruction in whole or in part;

(d) Imposing measures intended to prevent births within the group;

(f) Forcibly transferring children of the group to another group. ${ }^{180}$

Prosecutions for genocide do not require that the constituent acts be committed in an international conflict; they can occur in an internal conflict or in time of peace. ${ }^{181}$ Thus, prosecuting forced impregnation as genocide does not require that the conflict be characterized as either national or international. ${ }^{182}$ Although forced impregnation is not explicitly listed as means of committing genocide, the Genocide Convention may be interpreted to include

stroy a whole people." Vulliamy, supra note 113, at 201. For a discussion of the 1951 Convention on the Prevention and Punishment of the Crine of Genocide and its relation to the atrocities committed in the former Yugoslavia, see generally HELSINKI WATCH, HUMAN RIGHTS WATCH, 1 WAR CRIMES IN BOSNIA-HERCEgOVINA 1-2 (1992) [hereinafter 1 WAR CRIMES IN BOSNLA-HERCEGOVINA].

179. Chinkin, supra note 1 , at 10 .

180. Genocide Convention, supra note 9, art. II.

181. See id. art. I. "The Contracting Parties confirm that genocide, whether committed in time of peace or in time of war, is a crime under international law which they undertake to prevent and to punish." Id.

182. Cf. supra text accompanying notes $40-43$. 
forced impregnation within the meaning of Article II if the acts are committed with "intent to destroy, in whole or in part, a national, ethnical, racial, or religious group."183

Forced impregnation serves such an mtent well. First, in addition to the rape that causes it, forced impregnation itself causes "serious mental harm"184 to members of the group by forcing Bosnian women to carry and bear the children of their attackers. ${ }^{185}$ In this context it may cause serious and perhaps permanent psychological damage to the women forcibly impregnated. ${ }^{186}$ They nay be traumatized and so psychologically scarred by the pregnancy that they are unable to have normal sexual or childbearing experiences with their own people. ${ }^{187}$ Women who have been raped suffer severe psychological trauna. ${ }^{188}$ Catherine Fisclier, a volunteer with the International Rescue Committee (an American-based relief agency), told reporters that the victims of rape and forced impregnation in Bosnia "talk about running out in front of cars. They want to die. They feel they're going crazy. Soine shudder every time a man conies near." 189 Many women would rather have died than live after being forced to carry the child of their assailant. One woman stated that she "wish[ed] that they lad gunned me down instead of what they did to me. They denigrated me, which will bear hard upon my body and soul as long as I live." 190 Forced impregnation requires women to endure severe psycloological trauma and to "perform the most intiniate and life-altering work imaginable: the gestation of her captor's child." 191

183. Genocide Convention, supra note 9, art. II. "The systematic rape and forced pregnancy of Muslim women and girls qualifies as genocide under all parts of this definition." Krass, supra note 1 , at 320 .

184. Genocide Convention, supra note 9, art. II (b).

185. GOLDSTEIN, supra note 6, at 17. Forced impregnation "entails special horror and special pain." Id. at 5.

186. See id.

187. See id.

188. One woman reported: "My husband's sister and mother were attacked in their home and raped. My sister-m-law was a virgin. After her rape she became silent and would not come out of her room." Sherry Stripling, A Bridge of Caring-Local Women Marshal Volunteer Efforts to Help Victims of the War in Bosnia, SEATTLE TIMES, June 6, 1994, at F1.

189. Ricchiardi, supra note 12 , at $1 \mathrm{~B}$.

190. 2 WAR CRIMES IN BOSNIA-HERCEGOVINA, supra note 6, at 177 (quoting a woman raped by Serb soldiers in the municipality of Kluc).

191. GOLDSTEIN, supra note 6 , at 27. 
Second, forced impregnation may cause "serious bodily harm"192 to members of the group, subjecting women to pregnancy while they are confined in detention camps, without the care of doctors. ${ }^{193}$ Presumably, girls raped at ages as young as twelve or thirteen ${ }^{194}$ have been forced to bear children at a time when they are not biologically mature enough to support a healthy pregnancy. ${ }^{195}$ The physical abuse involved in the forcible impregnation may affect the childbearing capacity of the Muslim victims. ${ }^{196}$ A woman may have problems during the pregnancy which impair her future ability to conceive and carry a child. ${ }^{197}$

Third, forced impregnation "deliberately inflict[s] on the group conditions of life calculated to bring about its physical destruction in whole or in part." ${ }^{198}$ A policy of rape is particularly damaging in the Bosmian Muslim culture, where a woinan may not be marriageable if sle lias been raped or carried the child of another man, ${ }^{199}$ because "the religion emphasizes virginity and cliastity before marriage. 1200 According to traditional Islamic culture, victims of rape "have been spoiled for inarriage and inotherliood [because they are] no longer virgins in a culture that condemns premarital sex and ostracizes even those women who have been [forc-

192. Genocide Convention, supra note 9, art. II (b).

193. "The World Health Organization estimates that a half-million women die each year from pregnancy-related causes." GOLDSTEN, supra note 6, at 17 (citations omitted).

194. See Final Report, supra note 94, at 56, 59.

195. See Alice Walker \& Pratibha Parmer, Warrior Marks: Female Genital Mutilation and the Sexual Blinding of WOMEN 297. Dr. Henriette Kouyate, a gynecologist specializing in obstetrics states:

[P]regnancies [of girls as young as ten years old] very often finish very badly. For the mother as well as the baby, because they are girls whose bodies are not fully developed by the time they are forced to bear children.

As a result, many girls have abortions, or they may have nervous breakdowns, and the mortality of the mother and infant is very high. Young girls may have vascular vaginal fistula because the womb is too small, the child cannot come out, so when they are giving birth the vagina may burst into the bladder. It is very traumatic, because those women are going to leak all their lives if they cannot go to surgical centers where doctors can try to renew the bladder.

Id.

196. See Krass, supra note 1 , at $320-21$.

197. See GOLDSTEIN, supra note 6 , at 24 .

198. Genocide Convention, supra note 9, art. II (c).

199. See Krass, supra note 1 , at 321 ; see, e.g., 2 WAR CRIMES IN BOSNIAHERCEGOVINA, supra note 6 , at 178 (recounting one rape victim's belief that rapes are concealed so that the victims can still marry).

200. Krass, supra note 1, at 321 (citing Feryal Gharari, Equality Now, Address at Smith College (Apr. 15, 1993)). 
ibly raped or assaulted]."201 Bosnian Muslim women have told investigators how their lives are shattered and that they are no longer marriageable. ${ }^{202}$ Mothers try to conceal the rape of their daughters so that they can niarry, and niarried women do not tell their liusbands in order to protect the marriage. ${ }^{203}$ Furthermore, if Bosnian women are pregnant with the babies of Serbs, they cannot be pregnant with children of their own people. The wonien who have been raped "have lost their families, their honies, and their futures." 204 Thus the alleged Serbian tactics are figuratively and literally nothing less than a military occupation of the woinb. ${ }^{205}$

To constitute a crime of genocide, the acts enumerated in the Genocide Convention must be committed with the intent to destroy the group, in whole or in part. To this end, there does not as yet appear to be any direct evidence of a governmental policy of forced impregnation in the case of the former Yugoslavia. Thus,

201. Pine, supra note 103 , at $13 \mathrm{~A}$. "If her culture has now branded her unmarriageable [and she gives the child up], she may also be giving up the only child she will ever have." GoLDSTEIN, supra note 6, at 18. Also, "in a culture where rape is perceived as staining its victims, making single women unmarriageable and married women subject to rejection by their husbands, hike rape but to a greater degree, forced impregnation '[d]ehiberately inflict[s] on the group conditions of life calculated to bring about its physical destruction." Id. at 23 (quoting Genocide Convention, supra note 6, art. II (c)).

202. A woman raped by Serb soldiers in the Rakovcani region of Northwest Bosnia stated that "[v]irginity is very important to us Muslims." 2 WAR CRIMES IN BOSN1AHERCEGOVINA, supra note 6 , at 172 .

203. The words of a woman raped in the municipality of Kljuc express the damage of rape and pregnancy to Muslim women: "What happened to me, happened to many, but the women keep it secret. It is shameful. Thus, the mother conceals it if it happened to her daughter so she can marry and if it happened to an older woman, slie wants to protect her marriage." 2 WAR CRIMES IN BOSNIA-HERCEGOVINA, supra note 6, at 178.

204. Pine, supra note 103, at 13A.

205. A pohicy of forced impregnation also would fall under the proscription of "measures intended to prevent births within the group." Genocide Convention, supra note 9, art. II(d). As Professor Francis Boyle argued before the International Court of Justice:

There have been numerous instances where rump Yugoslav soldiers rape for the express purpose of making sure that they produce "chetnik" babies. In other words, these Bosmian women were raped for the express purpose of preventing the birth of children who would be either Bosmian, or Muslim, or both. Thus, the rape of Bosnian women to produce "chetniks" would clearly constitute genocide within the meaning of Article II, Paragraph (d) of the Genocide Convention.

GoLDSTEIN, supra note 6, at 23-24 (quoting Statement of Professor Francis A. Boyle, General Agent for the Republic of Bosnia and Herzegovina before the International Court of Justice in the Case Concerning Application of the Convention on the Prevention and Pumishment of the Crime of Genocide (Bosnia-Herzegovina v. Yugoslavia (Serbia and Montenegro) (Apr. 1, 1993))). 
it is necessary to examine circumstantial evidence to determine what was the intent behind the pattern of forced impregnation. Also, it is necessary to differentiate pregnancy as a natural consequence of repeated rape from a conscious pohicy where impregnation is the goal of repeated rape, because if raped repeatedly most fertile woinen will become pregnant. ${ }^{206}$ Repeated rape alone is still "just" rape, but rape with the intent to impregnate is something more. Furthermore, when there is not only the intent to forcibly impregnate but also the intent to destroy a group of people, it is genocide.

Although circumstantial in nature, the evidence that women were raped over and over until they became pregnant, and that they were detamed for that purpose, indicates that commanders must have known that their soldiers were raping women until they are pregnant. That they did nothing to stop this further supports the inference that this was part of a policy to rape women until they became pregnant. ${ }^{207}$ Furthermore, commanders and government officials allegedly gave direct orders to rape and impregnate women. For example, according to soine sources, Velibor Ostojić, a minister in Radovan Karadžić's breakaway government, played a critical role in the systematic rape of women. ${ }^{208}$ Bosma's interior minister at the time of the capture of Foća said he received evidence froin wiretaps that "proved Ostojic had ordered the raping of women in Foć." ${ }^{209}$ Also, the Final Report states:

The majority of the rapes occurred from April to November 1992; fewer occurred in the following five months. In the same time period, the number of media reports increased from a few in March 1992 to a high of 535 news stories in January 1993 and

206. See GoLDSTEN, supra note 6, at 5-6 (arguing that forced impregnation should not be dismissed as an inevitable byproduct of mass rape).

Just as rape is too often seen as an inevitable byproduct of war, pregnancy is likely to be seen as an inevitable byproduct of rape. After all, pregnancy is what predictably happens to large numbers of women who are victims of mass rape, so long as they are not also the victims of mass murder. But impregnation is more than an inevitable consequence of rape. It is, or at least may be, one of its goals.

Id. at 14 .

207. See 2 WAR CRIMES IN BOSNIA-HeRCEgovina, supra note 6, at 8-9 (noting that "[t]he lack of pumishment of Serbian soldiers for their abuses implies complicity on the part of the civilian, military and police authorities of the self-proclaimed 'Serbian Republic'").

208. See, e.g., GUTMAN, supra note 8 , at 160-61.

209. Id. at 161 . 
529 in February 1993. This correlation could indicate that the media attention caused the decline. In that case, it would indicate that commanders could control the alleged perpetrators if they wanted to. This could lead to the conclusion that there was an overriding policy advocating the use of rape as a method of "ethnic cleansing," rather than a policy of omission, tolerating the widespread commission of rape. ${ }^{210}$

In the case of Bosnia-Herzegovina v. Yugoslavia, which came before the International Court of Justice (ICJ) in 1993, BosniaHerzegovina received a provisional order requiring Yugoslavia to take all measures within its powers to prevent genocide from taking place. ${ }^{211}$ Although Bosnia-Herzegovina had not asked the court for special consideration of rape in its Request for the Indication of Provisional Measures, ${ }^{212}$ the ICJ provisional measure accepted Bosnia-Herzegovina's assertion that rape is a inanifestation of genocide. ${ }^{213}$ The ICJ then adopted a provisional order that imphed, but did not explicitly state, that Yugoslav Serbs were committing acts of genocide because of their involvenent in ethnic cleansing. ${ }^{214}$

210. Final Report, supra note 94, at 56.

211. Application of the Convention on the Prevention and Punishment of the Crime of Genocide (Bosnia and Herzegovina v. Yugoslavia (Serbia and Montenegro)), Provisional Measures, Order of 8 April 1993, 1993 I.C.J. 3, II 52.A.(1), reprinted in 32 I.L.M. 888, 901 (1993) [hereinafter Bosnia-Herzegovina v. Yugoslavia, Provisional Order].

212. See id. at III 1-3, 32 I.L.M. at 891-93; Christine Gray, Application of the Convention on the Prevention and Punishment of the Crime of Genocide (Bosnia and Herzegovina v. Yugoslavia (Serbia and Montenegro)), Orders of Provisional Measures of 8 April 1993 and 13 September 1993, 43 INT"L \& COMP. L.Q. 704 (1994).

213. Bosnia-Herzegovina v. Yugoslavia, Provisional Order, supra note 211, III 40, 52.d, 32 I.L.M. at 899,901 .

214. The International Court of Justice mdicated, in a vote of 13 to 1 , that: The Government of the Federal Republic of Yugoslavia (Serbia and Montenegro) should ... ensure that any military, paramilitary or irregular armed units whicl may be directed or supported by it, as well as any orgamizations and persons which may be subject to its control, direction or influence, do not commit any acts of genocide, of conspiracy to commit genocide, of direct and public incitement to commit genocide, or of complicity in genocide, whether directed against the Muslim population of Bosnia and Herzegovina or against any other national, ethnical, racial or religious group.

Bosnia-Herzegovina v. Yugoslavia, Provisional Order, supra note 211, II 52.A.(2), 32 I.L.M. at 901. However, the court cautioned that its provisional order was not meant to prejudge the merits of the case. See id., II 51, 32 I.L.M. at 900. Concerned over the implication of guilt in paragraph 52.A.(2), one judge dissented, noting that the provisions in paragraph 52.A.(2) "are very close to a pre-judgment of the merits, despite the Court's recognition [m paragraph 51] that, im an order indicating provisional measures, it is not entitled to reach determinations of fact or law." Id., I 26, 32 I.L.M. at 902. 
Two complaints filed under the Alien Tort Claims Act, consolidated in the Southern District of New York, ${ }^{215}$ also alleged that Serbian leaders were responsible for genocidal rape and forced impregnation. ${ }^{216}$ In coinplaints against Radovan Karadžić, the Bosnian Serb leader, Muslim citizens of Bosnia-Herzegovina alleged that they were victims of forced impregnation (among other atrocities) carried out by a Bosnian Serb genocidal campaign conducted during the war in the former Yugoslavia. ${ }^{217}$ The suit alleged that the atrocities were part of a pattern of systematic abuses directed by Karadžici. ${ }^{218}$ The Second Circuit went further, saying the allegations that Karadžić orchestrated "a campaign of murder, rape, forced impregnation, and other forms of torture designed to destroy the religious and ethnic groups of Bosnian Muslims and Bosmian Croats ... clearly state a violation of the international law proscribing genocide."219 Karadžićs's petition for certiorari, arguing that the U.S. courts lacked jurisdiction and violated the pohtical question doctrine, was denied. ${ }^{220}$

\section{B. The International Tribunal}

The enormity of the atrocities committed in the former Yugoslavia is matched only by the mertia of the international political community over the last five years. Now that the war is over, an international tribunal is in place, and indictments lave been issued, ${ }^{221}$ it is time to address the crimes committed during the

215. See Doe v. Karadžic, 866 F. Supp. 734, 735 (S.D.N.Y. 1994), rev'd sub nom. Kadic v. Karadžic, 70 F.3d 232 (2d Cir. 1995), cert. denied, 716 S. Ct. 2524 (1996).

216. Kadic v. Karadžic, 70 F.3d 232, 236-37 (2d Cir. 1995) (reversing district court's dismissal for lack of subject matter jurisdiction under the Alien Tort Crimes Act), cert. denied 116 S. Ct. 2524 (1996).

217. Kadic, 70 F.3d at 236-37.

218. Doe, 866 F. Supp. at 737 .

219. Kadic, 70 F.3d at 242; see also Alex Michelini, War Crimes Suits OKD Here Victims vs. Karadžić, DaIly NEws, Oct. 14, 1995, at 37.

220. Karadžic v. Kadic, 116 S. Ct. 2524, 2524 (1996); see also James Vicini, Bosnian Serb Leader Loses U.S. Supreme Court Appeal, Reuters Ltd., BC Cycle, June 17, 1996, available in LEXIS, World Library, Txtlne File.

221. The Prosecutor may issue an indictment once he determines that a prima facie case exists. Report of the Secretary-General Pursuant to Paragraph 2 of Security Resolution 808 , supra note 70 , at 43 . The U.S. Representative has stated that a prima facie case means a "reasonable basis to believe that a crime [within the competence of the International Tribunal] has been committed by the person named in the imdictment." Provisional Verbatim Record of the Three Thousand Two Hundred and Seventeenth Meeting, U.N. SCOR S/PV.3217, 48th Sess., at 16-17 (May 25, 1993). 
war, including forced impregnation. Forced impregnation must be prosecuted in order to demonstrate that it will not be permitted as a tactic of war. And to fully punish this crime, it nust be prosecuted as a crime of genocide.

In May of 1993, the Security Council, in Resolutions 808 and 827, created the International Tribunal for the Prosecution of Persons Responsible for Serious Violations of International Humanitarian Law Committed in the Territory of the former Yugoslavia since 1991 (hereinafter the International Tribunal). ${ }^{222}$ This action followed extensive international media coverage of the war in the former Yugoslavia and increasing international pressure that atrocities committed in the name of ethnic cleansing, including the crime of rape, not go unpunished. ${ }^{223}$ Calls for the pumishment of rape in the former Yugoslavia have been made in numerous international fora, ${ }^{224}$ and the United Nations Security Council has responded to these calls. In 1993 the UN sent a niedical team to investigate rape in the former Yugoslavia. ${ }^{225}$ The results of this investigation clearly indicated that rape was occurring on a massive scale, and led to a resolution by the UN Commission on Human Rights placing rape, for the first time, clearly within the framework of war crimes. ${ }^{226}$ The Commission eventually called for the creation of today's International Tribunal. ${ }^{227}$

Modern international trials for "grave breaches" or "war crimes" have not occurred since World War II. ${ }^{228}$ The few war

222. The U.N. Security Council first authorized the creation of an ad hoc international tribunal in February 1993. See Report of the Secretary General Pursuant to Paragraph 2 of Security Council Resolution 808, supra note 70, at 3. Later, pursuant to the Security Council's request, the Secretary-General made proposals regarding the establishment of the International Tribunal. On May 25, 1993, the Security Council established the International Tribunal and adopted the statute proposed by the Secretary-General. S.C. Res. 827, U.N. SCOR, 48th Sess., 3217th mtg., U.N. Doc. S/25626 (1993), reprinted in 32 I.L.M 1203 (1993).

223. See Schwartz, supra note 81, at 69.

224. See Krass, supra note 1 at 318 ; Meron, supra note 16 , at 424 .

225. See Mazowiecki, supra note 72 , at 19 . A team of four medical experts visited Bosnia-Herzegovina on January 12-23, 1993. Id. at 4.

226. See id.

227. See Letter from the Secretary-General to the Security Council, supra note 42 , at 20.

228. The first imternational war crimes trial occurred in Breisach, Germany in 1474. The tribunal was appointed by an anti-Burgundian military alliance in the name of the Holy Roman Empire. It convicted and executed the Burgundian commander Peter von Hagenbach. Hagenbach was found guilty of murder, rape and assorted other crimes committed pursuant to his orders by his soldiers while he was military governor of Breisbach. 
criminals brought to trial for war crimes since the 1940s have been tried under national rather than international law. ${ }^{229}$ The International Tribunal will be the first international forum since World War II to adjudicate war crimes, including not only rape, but also, potentially, forced impregnation. Previously, prosecutions for rape have been handled almost exclusively by national justice systems, civil or military. 230

The International Tribunal's founding statute outlines the crimes over which it has competence. ${ }^{231}$ Under the Genocide Convention, any court that has jurisdiction over a perpetrator can try him for genocide. ${ }^{232}$ The International Tribunal has jurisdiction over "persons responsible for serious violations of international humanitarian law committed in the territory of the former Yugoslavia since 1991 [the beginning of the conflict]."233 A prevailing principle of the court, nullum crimen sine lege, ${ }^{234}$ requires that the definition of each offense rely upon pre-existing custoinary and conventional international humanitarian law. ${ }^{235}$ Thus, the International Tribunal is coinpetent to prosecute the perpetrators of war crimes, genocide and crimes against humamity, ${ }^{236}$ all of which are clearly part of international humanitarian law. Further-

Hagenbach's prosecutors relied on "the laws of God and man." GEORG SCHWARZENBERGER, THE LAW OF ARMED CONFLICT 462-66 (1968).

229. See BEST, supra note 17 , at 420.

230. See, Meron, supra note 18, at 123-24; BEST, supra note 17 , at 420 .

231. Statute of the International Tribunal, in Report of the Secretary-General Pursuant to Paragraph 2 of Security Council Resolution 808, U.N. SCOR, 48th Sess., at Annex, U.N. Doc. S/25704 (1993) [hereinafter ICTY Statute]. The Statute of the International Tribunal was prepared by the UN Secretary-General and submitted to the Security Council in his Report of the Secretary-General Pursuant to Paragraph 2 of Security Council Resolution 808, supra note 70. The Secretary General proposed that the competence of the International Tribunal include grave breaches of the Geneva Conventions, violations of the laws and customs of war, genocide and crimes against humanity. See id.

232. Genocide Convention, supra note 9.

233. Report of the Secretary-General Pursuant to Paragraph 2 of Security Council Resolution 808 , supra note 70 , at 36 .

234. In Englisl1, "no crime without law." In selecting the categories of crimes encompassed by the Intemational Tribunal's Statute, the Secretary-General was guided by the consideration that "the application of the principle nullem crimen sine lege requires that the international tribunal should apply rules of international humanitarian law ... so that the problem of adherence of some but not all States to specific conventions does not arise." Id. at 9, I1 34. The crimes encompassed constitute "beyond doubt . . . part of international customary law . . . applicable in armed conflict . . . ." Id. at II 35.

235. Id.

236. The definition of crimes against humanity follows that of the Control Council Law No. 10, which includes rape. ICTY Statute, supra note 231, at Annex, art. 5. 
more, imternational humanitarian law was codified in the federal Criminal Code of Socialist Yugoslavia. ${ }^{237}$ The Geneva Conventions, Additional Protocol I to the Geneva Conventions and the Genocide Convention were incorporated in the Criminal Code

237. The Socialist Federal Republic of Yugoslavia ratified the Genocide Convention and the Geneva Conventions in 1950. The Genocide Convention was ratified on the basis of Article 74(9) of the Constitution of the Federal National Republic of Yugoslavia. Ukaz o ratifikaciji konvencije o sprecavanju i kažnjavanju zlocina genocida [Edict on the Ratification of the Convention for the Prevention and Punishment of Genocide], Službeni vesnik Prezidijuma Narodne skupštine Federativne Narodne Republike Jugoslavije (FNRJ) [Official Herald of the National Assembly of the Federal National Republic of Yugoslavia (FNRY)] [hereinafter Službeni vesnik], No. 2/50; Ustav Federativne Narodne Republike Jugoslavije [Constitution of the Federal National Republic of Yugoslavia] art. 74(9), Službeni list No. 1946.

As with the Genocide Convention, ratification of the Geneva Conventions was made by the FNRY National Assembly on the basis of Article 74(9) of the Constitution of the Federal National Republic of Yugoslavia. Ukaz 0 ratifikaciji konvencije 0 postupanju sa ratnim zarobljenicima, Konvencije sa poboljsanje sudbine ranjenika $i$ bolesnika $\mathfrak{u}$ oružanim snagama $u$ ratu, Konvencije sa poboljšanje sudbine ranjenika, bolesnika i brodolomnika oružanih pomorskih snaga i konvencije o zastiti gradjanskih lica za vreme rata, zaklucenih u Ženevi 12 Avgusta 1949 Godine - Uz odgovarajuce rezerve vlade FNRJ [Edict on the Ratification of the Convention Relative to the Treatnent of Prisoners of War, The Convention for the Amelioration of the Condition of the Wounded and Sick in Armed Forces in the Field, The Convention for the Amelioration of the Condition of the Wounded, Sick and Shipwrecked Members of the Armed Forces at Sea, and The Convention Relative to the Protection of Civilian Persons in Time of War, Concluded in Geneva 12 August 1949 - With corresponding reservations of the government of the FRNY], Sluzbeni vesnik, No. $6 / 50$.

The law in these treaties was codified in Chapter XI, Crimes Against Humanity and International Law, of the 1951 Code. See Krivichi zakon Federativne Narodne Republike Jugoslavije (1951) [Criminal Code of the Federal National Republic of Yugoslavia], Službeni list FNRJ, No. 13/51. The 1959 changes to the 1951 Criminal Code added to, but did not significantly alter, the nature of Chapter XI. See Zakon o izmenama i dopunama krivižnog zakonika Federativne Narodne Republike Jugoslavije (1959) [Law of Changes and Additions to the Criminal Code of the Federal National Republic of Yugoslavia], arts. 64-69, Službeni list FNRJ, No. 30/59. The changes made in criminal law and embodied in the 1977 Criminal Code also left Chapter XI of the previous code essentially intact. It then mcluded Crimes Against Humanity and International Law in Chapter XVI. See Krivicni zakon Socijalisticke Federativne Republike Jugoslavije (1977) [Criminal Code of the Socialist Federal Republic of Yugoslavia], Službeni list SFRJ, No. 44/76. The last changes to the 1977 Criminal Code were made in 1990, when provisions from Additional Protocol I were added to the code. The last changes to Chapter XVI, before the break up, were made in 1990 when Additional Protocol I was incorporated into the Criminal Code. Zakon o izmenama i dopunama krivižnog zakona Socijalisticke Federativne Republike Jugoslavije (1990) [Law of Changes and Additions to the Criminal Code of the Socialist Federal Republic of Yugoslavia], Službeni list No. 38/90; see also, Dylan Cors \& Siobhán K. Fisher, Criminal Sentencing and the ad hoc International War Crimes Tribunal for the Former Yugoslavia, (Oct. 1996) (unpublished manuscript, on file with author). 
prior to the breakup. ${ }^{238}$ Thus, all of the crimes which the International Tribunal is competent to prosecute were already codified in the national penal law of the former Yugoslavia. ${ }^{239}$

The International Tribunal recognizes rape and forced prostitution as crimes against humanity. ${ }^{240}$ However, the statute of the International Tribunal inakes clear that to constitute a crime agamst humanity the act must be committed as part of a widespread or systematic attack on a civilian population. ${ }^{241}$ Thus, individual rape cases cannot be prosecuted as a crime against huinanity. It is not entirely clear how the International Tribunal will deal with crimes specifically against women. In a recent conversation, a Senior Legal Advisor to the International Tribunal, indicated that the Office of the Prosecutor of the Tribunal intends to prosecute the crime of rape. ${ }^{242}$

Article 4 of the Statute of the International Tribunal for the Former Yugoslavia is modeled on the 1948 Convention on the Prevention and Punishment of the Crime of Genocide. ${ }^{243}$ The statute's definition of genocide copies the Genocide Convention verbatim: "[g]enocide ineans any of the following acts committed with intent to destroy, in whole or in part, a national, ethnical, racial or religious group, as such."244 The Statute follows the enumeration in the Genocide Convention of the acts which constitute genocide, and provides for "conspiracy to commit genocide; direct and public incitennent to commit genocide; attempt to commit genocide; and complicity in genocide."245 "Rape, forced impregnation and forced maternity, when committed as part of a campaign of genocide, should be explicitly acknowledged as genocidal acts under. Article 4."246

The most intractable problein im prosecuting forced impregnation as a crime of genocide appears to be determining the level of

238. See supra note 237.

239. Id.

240. The ICTY statute lists rape as a crime against humanity, see ICTY Statute, supra note 231, at Annex, art. 5, and was adopted by the Security Council. See S.C. Res. 827, supra note 220 , at 2 .

241. See ICTY Statute, supra note 231, at Annex.

242. See Interview with Commander William Fenrick, Senior Legal Advisor to the International Tribunal, in Durhani, N.C. (Mar. 12, 1995).

243. Compare ICTY Statute, supra note 231, with Genocide Convention, supra note 9.

244. ICTY Statute, supra note 231, at Annex art. 4.

245. Id. art. $4(3)$.

246. Green et al., supra note 58, at 188. 
proof necessary to satisfy the requisite intent. ${ }^{247}$ If intent can be proven, however, a policy of forced impregnation clearly surpasses the threshold of intent to interfere with the reproductive processes of the group. Prosecuting an individual instance of rape or forced impregnation as genocide is unlikely because, although a single act by an individual technically can be genocide under both the Tribunal statute and the Genocide Convention, it is unclear whether an individual act would in fact be considered genocide by the International Tribunal. ${ }^{248}$ The International Tribunal is more likely to consider prosecuting those responsible for a policy of mass rape and forced impregnation.

The precedential value of decisions of the International Tribunal is of great value. "Although, formally, the law stated by the Security Council under Chapter VII is necessarily contextual and applicable only to [the] former Yugoslavia, the [international] tribunal's charter, like that of Nuremberg, is likely quickly to becoine a fundamental normative instrument of the general law of war."249 Recognition by the Security Council, acting under Chapter VII of the U.N. Charter, of forced impregnation as a crime of genocide will have precedential impact on both national and international war crimes trials. ${ }^{250}$

\section{CONCLUSION}

The evidence strongly suggests that forced impregnation has been used as "a tool of ethnic cleansing" in the former Yugoslavia. $^{251}$ In the case of forced impregnation, women are special targets because of their reproductive power. They perpetuate the population; their wombs hold the future of the group. If women are rendered unable to bear children of their own people, the continued existence of the group is threatened. If their wombs are

247. See Genocide Convention, supra note 9, at 280.

248. Discussions with Senior Legal Advisor to the International Tribunal Commander William Fenrick and former Chief Prosecutor Richard Goldstone indicate that the burden of proof with regard to prosecuting an individual make prosecutions for such acts unlike1y. Interview with Commander Williain Fenrick, Senior Legal Advisor to the Intemational Tribunal, and Justice Richard Goldstone (Nov. 6, 1994).

249. Meron, supra note 16 , at 428 .

250. Cf. id. (stating that approval of the U.N. Charter may encourage recognition of rape as an instrument of torture under international human rights law).

251. Wu, supra note 96, at 101 (citing 1 WAR CRIMES IN BOSNIA-HERCEGOVINA, supra note 178 , at 10$)$. 
occupied, the reproductive self-determination of a people is eviscerated.

"In a decentralised legal system where principles of customary international law are generated througl State practice and opinio juris the conclusions of the International Tribunal resting upon the authority of the Security Council will inevitably have normative and educative effect" on the crime of forced impregnation under international law. ${ }^{252}$ The manner in which the International Tribunal treats the crime of forced impregnation will substantially affect precedent in international humanitarian law. This is one of the numerous reasons why a policy of forced unpregnation slrould be prosecuted under the Genocide Convention. If the International Tribunal were to prosecute forced impregnation during the Yugoslav war under the Genocide Convention, it would greatly imcrease the perception of rape as a method of waging war. These prosecutions would do much to dispel the notion that rape is a "sideline" atrocity. A policy of forced impregnation is not only a war crime, simply an ordinary crime, or "merely" soldiers taking the spoils of war-it is genocide. For the people of Bosnia-Herzegovina and for the international commumity, a policy of forced impregnation can and should be prosecuted as such.

252. Christine M. Chinkin, Rape and Sexual Abuse of Women in International Law 14 (unpublished manuscript on file with author). 
